\title{
Article \\ Chitosan Nanoparticles Inactivate Alfalfa Mosaic Virus Replication and Boost Innate Immunity in Nicotiana glutinosa Plants
}

\author{
Ahmed Abdelkhalek ${ }^{1, *}{ }^{\oplus}$, Sameer H. Qari ${ }^{2}{ }^{\circ}$, Mohamed Abd Al-Raheem Abu-Saied ${ }^{3}$, Abdallah Mohamed Khalil ${ }^{4}$, \\ Hosny A. Younes ${ }^{5}$, Yasser Nehela ${ }^{6,7}$ (D) and Said I. Behiry ${ }^{5, *(D)}$ \\ 1 Plant Protection and Biomolecular Diagnosis Department, ALCRI, City of Scientific Research \\ and Technological Applications, New Borg El-Arab City 21934, Alexandria, Egypt \\ 2 Biology Department, Al-Jumum University College, Umm Al-Qura University, Mecca 25376, Saudi Arabia; \\ shqari@uqu.edu.sa \\ 3 Polymeric Materials Research Department, Advanced Technology and New Materials Research Institute, \\ City of Scientific Research and Technological Applications (SRTA-City), New Borg El-Arab City 21934, \\ Alexandria, Egypt; Maabusaied@srtacity.sci.eg \\ 4 Plant Botany Department, Faculty of Science, Omar Al-Mukhtar University, Al Bayda 00218-84, Libya; \\ abdallak805@gmail.com \\ 5 Agricultural Botany Department, Faculty of Agriculture (Saba Basha), Alexandria University, \\ Alexandria 21531, Egypt; hosnyyounes@yahoo.com \\ 6 Department of Agricultural Botany, Faculty of Agriculture, Tanta University, Tanta 31511, Egypt; \\ yasser.nehela@ufl.edu \\ 7 Citrus Research and Education Center, Department of Plant Pathology, University of Florida, \\ 700 Experiment Station Rd., Lake Alfred, FL 33850, USA \\ * Correspondence: aabdelkhalek@srtacity.sci.eg (A.A.); said.behiry@alexu.edu.eg (S.I.B.)
}

Citation: Abdelkhalek, A.; Qari, S.H.; Abu-Saied, M.A.A.-R.; Khalil, A.M.; Younes, H.A.; Nehela, Y.; Behiry, S.I Chitosan Nanoparticles Inactivate Alfalfa Mosaic Virus Replication and Boost Innate Immunity in Nicotiana glutinosa Plants. Plants 2021, 10, 2701. https://doi.org/10.3390/plants10122701

Academic Editor: Rene Kizek

Received: 5 November 2021

Accepted: 3 December 2021

Published: 8 December 2021

Publisher's Note: MDPI stays neutral with regard to jurisdictional claims in published maps and institutional affiliations.

Copyright: (c) 2021 by the authors Licensee MDPI, Basel, Switzerland. This article is an open access article distributed under the terms and conditions of the Creative Commons Attribution (CC BY) license (https:// creativecommons.org/licenses/by/ $4.0 /)$.
Abstract: Plant viral infection is one of the most severe issues in food security globally, resulting in considerable crop production losses. Chitosan is a well-known biocontrol agent against a variety of plant infections. However, research on combatting viral infections is still in its early stages. The current study investigated the antiviral activities (protective, curative, and inactivation) of the prepared chitosan/dextran nanoparticles (CDNPs, $100 \mu \mathrm{g} \mathrm{mL}^{-1}$ ) on Nicotiana glutinosa plants. Scanning electron microscope (SEM) and dynamic light scattering analysis revealed that the synthesized CDNPs had a uniform, regular sphere shapes ranging from 20 to $160 \mathrm{~nm}$ in diameter, with an average diameter of $91.68 \mathrm{~nm}$. The inactivation treatment was the most effective treatment, which resulted in a $100 \%$ reduction in the alfalfa mosaic virus (AMV, Acc\# OK413670) accumulation level. On the other hand, the foliar application of CDNPs decreased disease severity and significantly reduced viral accumulation levels by $70.43 \%$ and $61.65 \%$ in protective and curative treatments, respectively, under greenhouse conditions. Additionally, the induction of systemic acquired resistance, increasing total carbohydrates and total phenolic contents, as well as triggering the transcriptional levels of peroxidase, pathogen-related protein-1, and phenylalanine ammonia-lyase were observed. In light of the results, we propose that the potential application of CDNPs could be an eco-friendly approach to enhance yield and a more effective therapeutic elicitor for disease management in plants upon induction of defense systems.

Keywords: chitosan nanoparticles; alfalfa mosaic virus; antiviral activity; gene expression

\section{Introduction}

Plant viruses are one of the main plant pathogens that pose a severe threat to sustainable agriculture and food security throughout the world [1]. Among them, the Alfalfa mosaic virus (AMV) is one of the most significant and widely spread viruses in Egypt, causing severe crop losses [2,3]. AMV can infect more than 430 plant species belonging to 51 families, causing mild to severe leaf symptoms, dark green mottle counting, brilliant yellow mottle, necrotic or chlorotic lesions, leaf deformation, vein necrosis, and ring spots, 
among others [2,4]. In nature, AMV is transmitted in a non-persistent manner by sap inoculation and a variety of 25 aphid species, as well as by seeds and pollen in some plant species [5]. Under greenhouse conditions, AMV-like symptoms were clearly observed after 14 to 21 days of viral inoculation depending on the type of host plant and cultivar [3,6-8]. Due to limited control methods, new viral disease management strategies have been proposed in order to achieve better and more sustainable viral disease control. Such ways depend on promoting natural plant defense, e.g., systemically acquired resistance (SAR) $[9,10]$. The early recognition of pathogens is critical for plants' natural defense mechanism against pathogenesis. Commonly, the stimulation of a natural defense response involves increased expression of defense-related genes and enzymes as well as increased phenolic compound accumulation [11]. Plants treated with various biotic elicitor molecules have been demonstrated to elicit this innate immune response the same way that infections do $[12,13]$.

Chitosan, a natural polymer, has been found to be an efficient biotic elicitor in plants causing systemic resistance development [14]. Chitosan is a well-known biocontrol agent and abundant dual-effect natural polymer due to its non-toxic, biodegradable, and biocompatible characteristics [15]. Chitosan application could prevent the microbial pathogens from growing and sporulating by disrupting the membranes of their cells and inhibiting various biochemical processes during the plant-pathogen interaction, which causes distinct defensive responses in host plants. Because of the challenges and unique needs of growing viruses, chitosan's antiviral activity (and derivatives) has received little attention. However, some information about chitosan's antiviral action may be found in the literature, and several studies have shown that chitosan protects plants from viral infection [16-18]. Chitosan, for example, has been shown to successfully induce viral resistance in plants such as tomatoes, cucumbers, potatoes, sunflowers, and tobacco $[17,18]$. It was reported that the chitosan biopolymer's unique features could be further strengthened by employing them as nanoparticles. In this form, it can impart varied biological activities with altered physicochemical qualities such as size, cationic nature, and surface area [19]. In this context, nanomaterials have emerged as a potential technical innovation that has the ability to alter the agriculture sector by enhancing crop productivity, promoting plant-systemic resistance, and combating phytopathogens.

Several studies have been published on the up-regulation of defense-related enzymes/genes in several crop plants by chitosan nanoparticles [19-22]. Compared to chitosan, the foliar application of finger millet plants with chitosan nanoparticles $(0.1 \%, w / v)$ significantly enhanced growth, yield, mineral content, and several defense enzymes such as peroxidase, chitinase, and polyphenol oxidase [23]. Furthermore, the biostimulant activity of chitosan nanoparticles in a variety of agricultural crop plants was reported [21-24] However, research to combat viral infections is still beginning $[25,26]$. Consequently, the current study aimed to synthesize and characterize chitosan/dextran nanoparticles (CDNPs) using dynamic light scattering (DLS), scanning electron microscope (SEM), and Fourier transform-infrared (FTIR) spectroscopy. In addition, a range of immune-related responses to differing CDNP treatments (protective, curative, and inactivating) was evaluated. To this end, we studied the effects of CDNPs on inducing SAR and transcriptional levels of defenserelated genes (peroxidase $(P O D)$, pathogen-related protein-1 $(P R-1)$, and phenylalanine ammonia-lyase $(P A L))$, as well as total carbohydrates and total phenolic content.

\section{Materials and Methods}

\subsection{Preparation of Chitosan/Dextran Nanoparticles}

Chitosan (molecular weight: 100,000-300,000), dextran sulfate, glacial acetic acid extra pure $(99.5-100 \%, \mathrm{M} . \mathrm{W}=60.05)$, and sodium hydroxide $(\mathrm{NaOH})$ assay $(97 \%$, Fisher Chemical, Chicago, IL, USA) were used to prepare chitosan dextran nanoparticles (CDNPs) via the ionic-gelation method [27]. Briefly, $0.2 \% w / v$ chitosan solution in $1 \% v / v$ glacial acetic acid was prepared and adjusted to the $\mathrm{pH}$ value of 5 by adding, drop by drop, $1 \mathrm{~N}$ $\mathrm{NaOH}$. On the other hand, $0.2 \% w / v$ dextran solution in distilled water was prepared. 
Dextran solution was added slowly drop by drop into the chitosan solution at a 1:2 ratio under magnetic stirring at $700 \mathrm{rpm}$ for $30 \mathrm{~min}$ to form CDNPs. After that, the obtained CDNPs were further characterized.

\subsection{Characterization of Chitosan/Dextran Nanoparticles}

A scanning electron microscope (SEM) was used to examine the morphology of the nanoparticles. The nanoparticle sample was placed on a self-adhesive carbon disc and placed on a $25 \mathrm{~mm}$ aluminum stub with a sputter coater. The stub was coated with $25 \mathrm{~nm}$ gold and then imaged on an FEI Quanta 200 FEG (SEM) at 5kV. Finally, secondary electron detection was used to accelerate voltages [28]. A Fourier Transform Infra-Red (FTIR) spectroscopy instrument (Shimadzu FTIR-8400 S, Japan) was used to investigate different functional groups of the prepared CDNPs. The samples were ground gently with $300 \mathrm{mg}$ of micronized potassium bromide $(\mathrm{KBr})$ powder and compressed into discs at a force equal to $10 \mathrm{kN}$ for $2 \mathrm{~min}$. A 256-scan interferogram was collected for each spectrum at room temperature to investigate the success of the synthesis process [29].

\subsection{Viral Isolation and Molecular Characterization}

Samples of potatoes (Solanum tuberosum L.) exhibited characteristics of AMV-like symptoms, including brilliant mottling and yellow blotching, and were obtained from Egypt's farms. All samples were analyzed for viral presence using Double Antibody Sandwich-Enzyme-Linked Immunosorbent Assay (DAS-ELISA) with specific antiserum (DSMZ, AS-0779) [30,31]. The purified single local lesion developed on Chenopodium amaranticolor leaves, as a local lesion host for $\mathrm{AMV}$, was used as a viral source to inoculate Nicotiana glutinosa plants in an insect-proof greenhouse. According to the manufacturer's instructions, the QIAamp Viral RNA Kit was used to extract viral RNA (QIAGEN, Hilden, Germany). As previously described [32,33], first-strand cDNA was generated and subjected to PCR to amplify the $A M V-C P$ gene before sending it to sequence at Macrogen company (Seoul, Korea). The nucleotide sequence was deposited in GenBank to obtain the accession number.

\subsection{Greenhouse Antiviral Activity Assays and Experimental Design}

The uniform N. glutinosa seeds were surface sterilized and cultivated in plastic pots ( $25 \mathrm{~cm}$ in diameter) filled with sterilized soil. At the 5-6th leaf stage, N. glutinosa seedlings were transported to new pots; each pot contained three plants, and after one week of transplantation, plants of similar sizes were subjected to antiviral assays. The purified inoculum concentration of AMV was diluted to $20 \mu \mathrm{g} \mathrm{mL}^{-1}$ with $0.01 \mathrm{M}$ phosphate buffer before use, while CDNPs $(0.01 \%, w / v)$ were dispersed in sterile distilled water. As previously described [34], two true upper leaves of each plant were dusted with carborundum (600 mesh) and mechanically inoculated with the virus-inoculum $(100 \mu \mathrm{L} /$ leaf $)$. Five treatmentscontrol (mock-inoculated control), infected (AMV-inoculated control), protective, curative, and inactivating-were performed on N. glutinosa plants. The N. glutinosa plants treated with CDNPs $\left(100 \mu \mathrm{g} \mathrm{mL}^{-1}\right) 24 \mathrm{~h}$ before AMV inoculation served as a protective treatment. In comparison, plants treated with CDNPs $\left(100 \mu \mathrm{g} \mathrm{mL} \mathrm{m}^{-1}\right), 24 \mathrm{~h}$ after AMV mechanical inoculation, were used as curative treatment. For inactivating treatment, an equal volume of purified AMV $\left(20 \mu \mathrm{g} \mathrm{mL}^{-1}\right)$ and CDNPs $\left(100 \mu \mathrm{g} \mathrm{mL}^{-1}\right)$ was mixed and incubated for $1 \mathrm{~h}$ before mixture inoculation ( $200 \mu \mathrm{L} /$ leaf), and CDNPs foliar application. The whole plant shoots were foliar sprayed until run-off, and the leaves appeared to be coated with the solution using a handheld pressure sprayer. The N. glutinosa plants inoculated with AMV alone were used as an infected treatment. As a negative control, mock-treated plants were inoculated with viral inoculation buffer and foliar sprayed with sterile distilled water. All plants were kept under greenhouse conditions $\left(28^{\circ} \mathrm{C} / 16^{\circ} \mathrm{C}, 16 \mathrm{~h} / 8 \mathrm{~h}\right.$ light/dark cycle, and relative humidity of $70 \%$ ), and symptom development was recorded regularly for 20 days. For further analysis, three independent biological replicates of N. glutinosa leaves of all treatments were collected at 3, 6, 10, 15, and 20 days post-inoculation (dpi). The DAS-ELISA 
test was performed on all the treatments to determine AMV systemic accumulation level as previously described [30].

\subsection{Estimation of Total Phenolic Content}

Total phenolic content (TPC) was estimated as described by Jindal and Singh [35]. Five hundred milligrams of dried plant tissues were extracted with absolute ethanol, centrifuged, and the supernatant was mixed with a mixture of Folin-Ciocalteu reagent and sodium carbonate $20 \%(1: 1 \mathrm{v} / \mathrm{v})$. The combination was completed with $10 \mathrm{~mL}$ of deionized water and kept in the dark for $30 \mathrm{~min}$. A double beam spectrophotometer (OPTIMA, Japan) determined the absorbance values at $650 \mathrm{~nm}$. Different concentrations of pyrogallol were used to prepare the standard curve, and TPC values were determined as $\mathrm{mg} \mathrm{g}^{-1} \mathrm{DM}$ in the plant shoot.

\subsection{Determination of Total of Soluble Carbohydrates}

The phenol sulfuric acid method was used to estimate the total soluble carbohydrates, according to Dubois et al. [36]. N. glutinosa dried plants were ground to a fine powder. In the test tube, $0.1 \mathrm{~g}$ of plant powder was added to a $5 \mathrm{~mL}$ borate buffer containing $28.63 \mathrm{~g}$ boric acid, $29.8 \mathrm{~g}$ potassium chloride, and $3.5 \mathrm{~g}$ sodium hydroxide/L, $\mathrm{pH}$ 8.0. The tubes were kept for $24 \mathrm{~h}$ at $4{ }^{\circ} \mathrm{C}$, then centrifuged for $15 \mathrm{~min}$ at $3000 \mathrm{rpm}$. The collected supernatants were combined with $6 \mathrm{~mL}$ of a mixture of phenol 5\% and sulfuric acid (1:5) and placed in a water bath at $30^{\circ} \mathrm{C}$ for $20 \mathrm{~min}$. The resultant color was measured at $490 \mathrm{~nm}$. The total soluble carbohydrate content values were determined as $\mathrm{mg} \mathrm{g}^{-1} \mathrm{DM}$ using a calibration curve of glucose sugar.

\subsection{Transcriptional Levels of Defense-Related Genes}

By using the guanidium isothiocyanate extraction method [37,38], $100 \mathrm{mg}$ of N. glutinosa leaves collected at 3, 6, 10, 15, and 20 dpi for all treatments was utilized as starting material for total RNA extraction. After checking the concentration, purity, and integrity of the extracted RNA on Nano SPECTROstar and agarose gel electrophoresis, respectively, $1 \mu \mathrm{g}$ of DNase-treated total RNA from each sample was used as a template for cDNA synthesis as previously described [39]. The reverse transcription reaction was incubated at $42{ }^{\circ} \mathrm{C}$ for $1 \mathrm{~h}$, then inactivated at $80{ }^{\circ} \mathrm{C}$ for $7 \mathrm{~min}$ and stored at $-20{ }^{\circ} \mathrm{C}$ until used. For detecting the expression profiles of the three $N$. glutinosa genes (PAL, PR-1, and POD), the synthesized cDNA was subjected to qRT-PCR amplification using a specific primer (Table 1). A real-time cycler (Corbett Rotor-Gene Q, Qiagen, Manchester, UK) was used to amplify all genes transcripts with program features as described previously [40]. The $\beta$-actin reference gene (Table 1) was applied to normalize the transcript expression of each gene. The qRT-PCR amplification program consisted of an initial denaturation at $95^{\circ} \mathrm{C}$ for $10 \mathrm{~min}$, followed by 45 cycles programmed as $95{ }^{\circ} \mathrm{C}$ for $20 \mathrm{~s}, 60{ }^{\circ} \mathrm{C}$ for $30 \mathrm{~s}$, and $72{ }^{\circ} \mathrm{C}$ for $30 \mathrm{~s}$. Reactions of each sample were performed with three technical replicates. The relative expression levels were quantified according to Livak and Schmittgen [41].

Table 1. List of the nucleotide sequences of the qRT-PCR primers used in this study.

\begin{tabular}{|c|c|c|c|}
\hline Primer Name & Abbreviation & Direction & Sequence $\left(5^{\prime} \ldots\right.$ \\
\hline \multirow{2}{*}{$\begin{array}{l}\text { Alfalfa mosaic virus-coat } \\
\text { protein }\end{array}$} & \multirow{2}{*}{$A M V-C P$} & Forward & CCATCATGAGTTCTTCACAAAAG \\
\hline & & Reverse & TCGTCACGTCATCAGTGAGAC \\
\hline \multirow{2}{*}{ Peroxidase } & \multirow{2}{*}{$P O D$} & Forward & TGGAGGTCCAACATGGCAAGTTCT \\
\hline & & Reverse & TGCCACATCTTGCCСTTCCAAATG \\
\hline \multirow{2}{*}{$\begin{array}{l}\text { Pathogenesis related } \\
\text { protein-1 }\end{array}$} & \multirow{2}{*}{ PR-1 } & Forward & GTTCCTCCTTGCCACCTTC \\
\hline & & Reverse & TATGCACCCCCAGCATAGTT \\
\hline \multirow{2}{*}{$\begin{array}{l}\text { Phenylalanine } \\
\text { ammonia-lyase }\end{array}$} & \multirow{2}{*}{$P A L$} & Forward & GTTATGCTCTTAGAACGTCGCCC \\
\hline & & Reverse & CCGTGTAATGCCTTGTTTCTTGA \\
\hline \multirow{2}{*}{ Beta-actin } & \multirow{2}{*}{$\beta$-actin } & Forward & TGGCATACAAAGACAGGACAGCCT \\
\hline & & Reverse & ACTCAATCCCAAGGCCAACAGAGA \\
\hline
\end{tabular}




\subsection{Statistical Analyses}

Data of ELISA, total carbohydrates, and total phenolics were statistically analyzed according to the analysis of variance technique (ANOVA), followed by post hoc pairwise comparisons between them using the Tukey-Kramer honestly significant difference test (Tukey HSD, $p \leq 0.05$ ). Relative expression values of different defense-related genes $(P O D, P R-1$, and $P A L)$ were analyzed using full factorial ANOVA based on a split-plot design with five treatments (mock-inoculated control, AMV-inoculated control, protective, curative, and inactivating) in the main plots and six-time points $(0,3,6,10,15,20$ days post-inoculation) in subplots. Compared to mock-inoculated control treatment, the relative transcriptional values higher than 1 were classified as elevations in gene expression (upregulation/induction). In contrast, values lower than 1 were classified as declines in expression levels (down-regulation/suppression). In addition, based on the assumptions of linearity, simple linear regression (SLR) analysis was performed to model the relationship between time post-inoculation (as an independent variable) and relative expression levels of different defense-related genes including $P O D, P R-1$, and $P A L$ (as dependent variables). The fitted SLR line is expressed by the equation determined by the $\mathrm{F}$ test $(p \leq 0.05)$. Both the coefficient of determination $\left(R^{2}\right)$ and the adjusted coefficient of determination $\left(R^{2}{ }_{\text {adj }}\right)$ were also obtained. Additionally, because of the experiential nonlinear phenomena between time post-inoculation and relative expression levels of different defense-related genes $(P O D, P R-1$, and $P A L)$, and to better understand the curvilinear relationship between them, data were fitted with a second-degree polynomial regression model (quadratic model). Quadratic equation, $R^{2}, R^{2}$ adj, and $p$-value based on the $\mathrm{F}$ test $(p \leq 0.05)$ were also obtained. Both SLR and polynomial regression were carried out using JMP 15 Software from SAS (https:/ / www.jmp.com/en_us/home.html accessed on 3 December 2021).

\section{Results and Discussion}

\subsection{Structural, Compositional Characterization, and Particle Size of the Synthesized CDNPs}

Scanning electron microscopy (SEM) is a widely used method for determining the surface morphology of nanoparticles [26]. In the present study, the SEM analysis showed that the CDNPs have uniform, regular, and spherical shapes with a little aggregation between them (Figure 1A). Dynamic light scattering (DLS) is a popular method for determining particle size distribution in aqueous/colloidal solutions [42]. The DLS analysis revealed that the diameter range of the prepared CDNPs was between 20 and $160 \mathrm{~nm}$, with an average diameter of $91.68 \pm 4.87 \mathrm{~nm}$ (Figure 1B).

\subsection{Infrared Spectrophotometry}

The FTIR spectra of pure chitosan (Figure 1C) exhibited characteristic broad band signals at 3346-3286 $\mathrm{cm}^{-1}$ referred to N-H and O-H groups, respectively [43]. A peak of amide I band appears at $1641 \mathrm{~cm}^{-1}$, and a strong protonated amino peak is at $1575 \mathrm{~cm}^{-1}$ [44]. Around $1370 \mathrm{~cm}^{-1}$ shows a peak corresponding to $\mathrm{C}-\mathrm{N}$ stretching, and $\mathrm{C}-\mathrm{O}-\mathrm{C}$ asymmetric stretching was found around $1143 \mathrm{~cm}^{-1}$ [45]. In dextran, sulfyl peaks presented at $1026 \mathrm{~cm}^{-1}$ and $1261 \mathrm{~cm}^{-1}$ due to symmetric and asymmetric stretching vibrations of (SOO-), and the band around $820 \mathrm{~cm}^{-1}$ correspondents to S-O-S vibrations [46]. In chitosan/dextran sulfate nanoparticles, the FTIR also shows a peak of amide bond at $1642 \mathrm{~cm}^{-1}$, and the strong protonated amino peak shifted from 1575 to $1559 \mathrm{~cm}^{-1}$ (Figure 1D). There was a peak shift in the sulfate stretching vibration spectrum from 1261 to $1256 \mathrm{~cm}^{-1}$. Changes in the amine group of chitosan and the sulfate group of dextran are caused by inotropic interaction between cationic and anionic molecules, respectively [45]. The FTIR spectra clarified the successful cross-linking between chitosan and dextran to form CDNPs. 

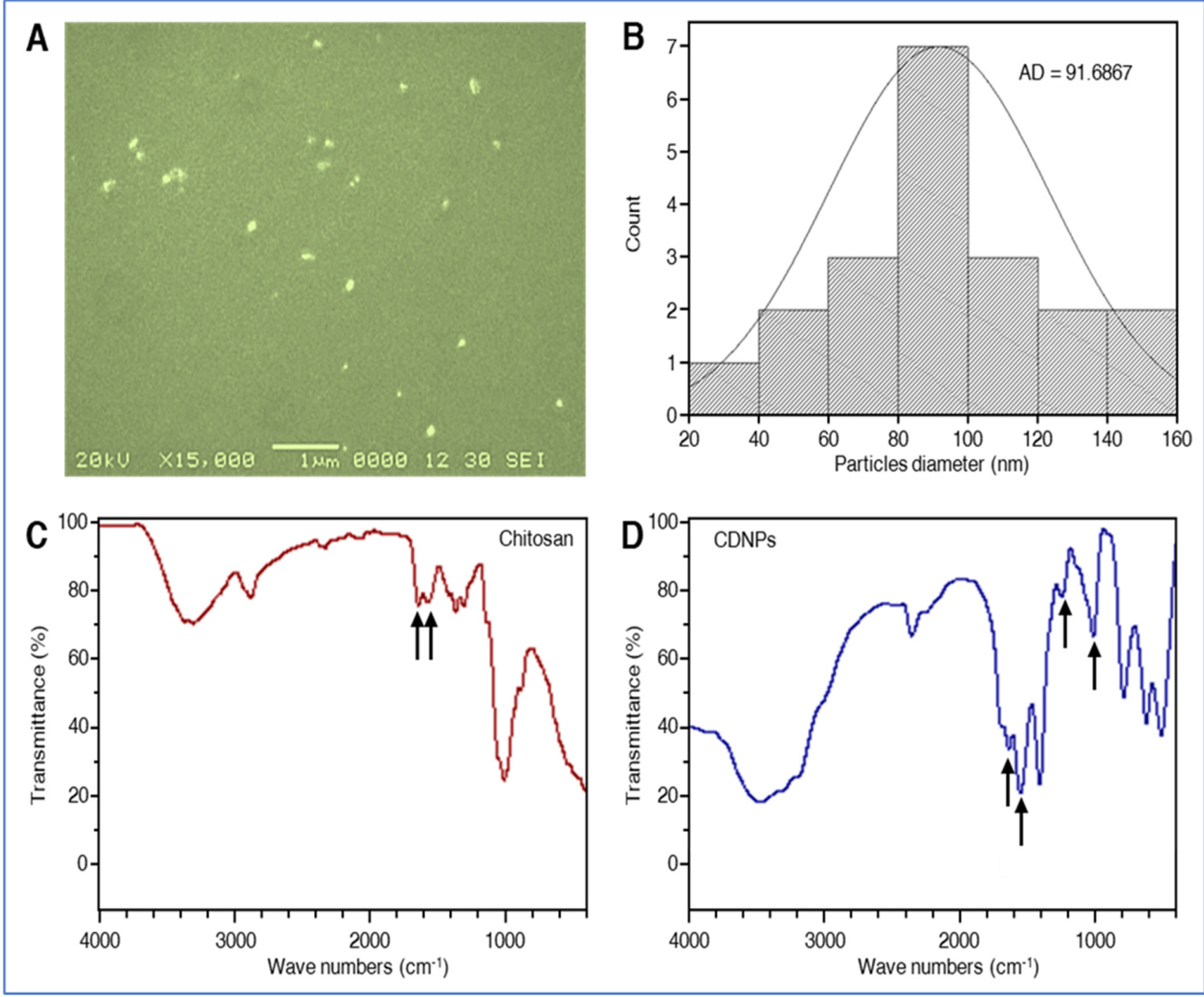

Figure 1. Structural and compositional characterization of chitosan/dextran nanoparticles (CDNPs). (A) SEM image of the prepared CDNPs, (B) particle size distribution of the synthesized CDNPs using dynamic light scattering technique. (Bar $=1 \mu \mathrm{m}$ at $\times 15,000),(\mathbf{C}, \mathbf{D})$ FTIR spectra of pure chitosan and CDNPs, respectively.

\subsection{Viral Isolation and Molecular Characterization}

The yellow blotching and bright mottling symptoms on the leaves were the common AMV symptoms in the field-collected potato (Solanum tuberosum L.) samples (Figure 2A). Most potato cultivars are susceptible to AMV infection, resulting in a variety of symptoms ranging from bright yellow blotching and mottling to clear visibility of calico symptoms $[2,3,47]$. At 4-5 dpi, single local lesions developed on Chenopodium amaranticolor leaves [48] and were used as a source of pure AMV isolate for purification and antiviral assay studies (Figure 2B). The sequence information of the viral coat protein $(\mathrm{CP})$ gene is a very important criterion for plant virus identification and taxonomy. Bromoviridae have a lot of variation in their $\mathrm{CP}$; in addition, it is the most useful molecule for their phylogeny [49].

In the present study, RT-PCR was performed on the extracted total RNA from infected plant tissues with specific $A M V-C P$ gene primers. Analysis of PCR products in agarose gel electrophoresis revealed that the amplification of a specific band was approximately $350 \mathrm{bp}$, which was in agreement with the size of the fragment expected from the sequence data reported previously [31]. After PCR product purification and sequencing, the annotated sequence was deposited in the GenBank database under isolate ASHA1 and accession number OK413670. According to NCBI-BLAST alignment, our Egyptian isolate (OK413670) shared the highest similarity of 99\% with the USA isolate (JX154092) and South Korea isolate (LC219343) while sharing a similarity of 98\% with other isolates from Egypt (LN846978 and LN846979). Moreover, isolate MW428250 showed a lower similarity of $97 \%$ with our isolate reported in this study. This result indicates that AMV isolates in Egypt have a lot of genetic variabilities. 
Moreover, the phylogenetic tree (Figure 3) analysis showed that the aligned AMV isolates were clustered into two subgroups, which could be related to their geographic origin [50].
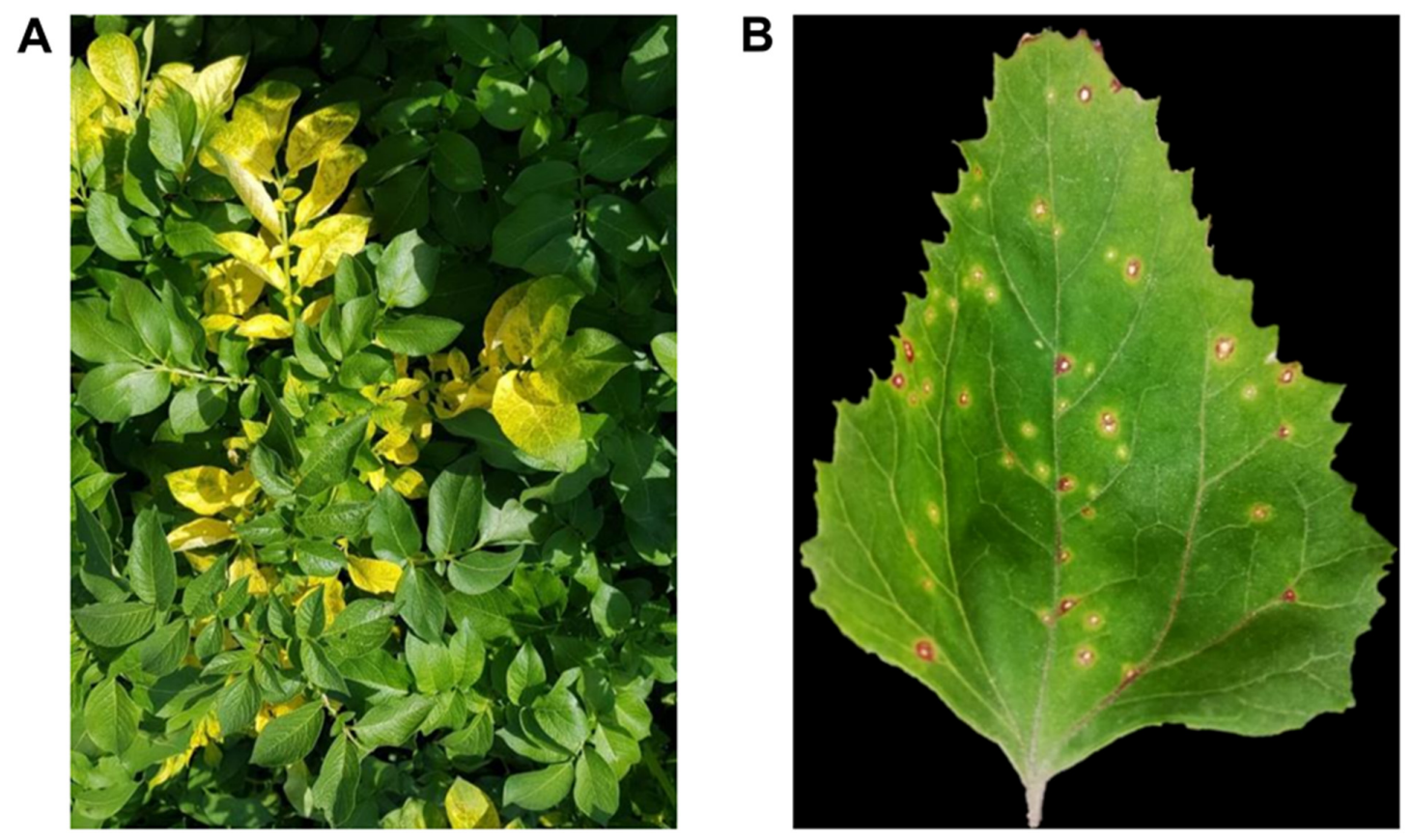

Figure 2. (A) Calico symptoms on naturally AMV-infected potato (Solanum tuberosum L.) plants; (B) local lesions developed on Ch. amaranticolor leaves in response to AMV after mechanical inoculation at 5 dpi.

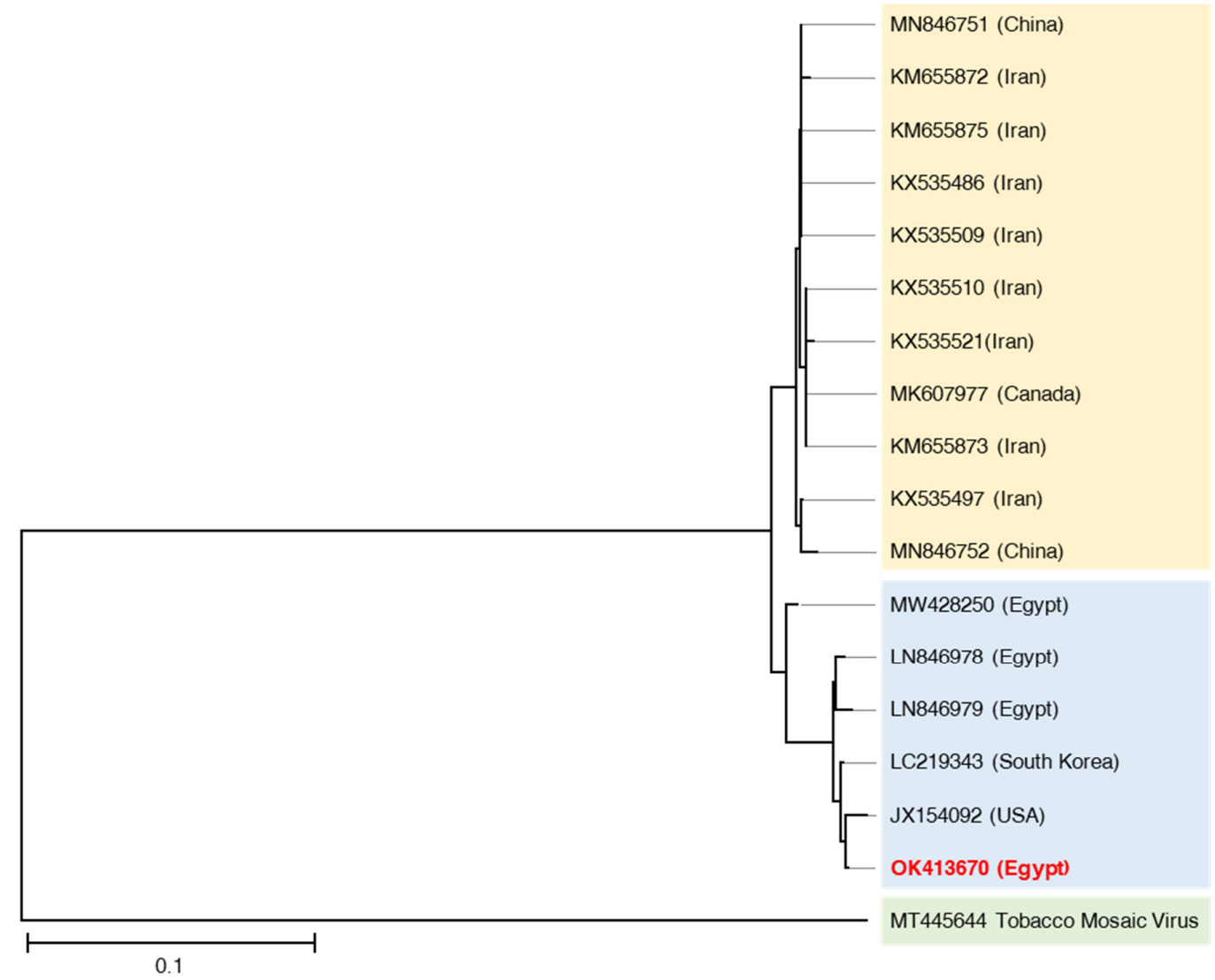

Figure 3. Phylogenetic tree based on the nucleotide sequence of the coat protein (CP) gene of the Egyptian alfalfa mosaic virus isolate OK413670, and other CP genes of AMV isolates retrieved from GenBank. The phylogeny was created using the UPGMA statistical approach and tested using the bootstrap method with 2000 replications. 


\subsection{Antiviral Activity of Chitosan/Dextran Nanoparticles (CDNPs)}

3.4.1. Effect of CDNPs on Disease Severity and AMV Systemic Accumulation Level

Under greenhouse conditions, the antiviral activity (protection, curation, and inactivation) of the prepared CDNPs against AMV on N. glutinosa was evaluated. The application of CDNPs $\left(100 \mu \mathrm{g} \mathrm{mL}^{-1}\right)$ significantly reduced the disease severity and decreased the AMV accumulation levels of the CDNPs-treated plants when compared to AMV-inoculated control treatment plants. At $20 \mathrm{dpi}$, and compared with mock-inoculated control (Figure 4A), the AMV-inoculated N. glutinosa control plants showed severe mosaic symptoms (Figure 4B). On the other hand, a delay in the appearance of the symptoms for four days was observed in CDNPs-treated plants $24 \mathrm{~h}$ before viral inoculation (protective treatment; Figure $4 \mathrm{C}$ ). Additionally, plants treated with CDNPs $24 \mathrm{~h}$ after viral inoculation (curative treatment) showed mild mosaic symptoms compared to AMV-inoculated control plants (Figure 4D). No symptoms were observed on either mock-inoculated control or inactivation treatment plants (Figure 4A,E, respectively). It was observed that foliar treatment of tomato and tobacco plants with chitosan $(0.1 \%, w / v) 24 \mathrm{~h}$ before CMV inoculation was associated with no deleterious symptom development [51]. On the other hand, spraying coffee seedlings with chitosan nanoparticles in the range of 420 to $970 \mathrm{~nm}$ for three times at a concentration of $10 \mathrm{ppm}$ improved chlorophyll and carotenoid contents, uptake of nitrogen and magnesium, as well as the growth of coffee in the pots under greenhouse conditions [52]. Compared to bulk chitosan, the foliar application of chitosan nanoparticles $(0.1 \%, w / v)$ significantly enhanced finger millet growth, yield, and mineral content [23]. Foliar-sprayed nanoparticles mainly enter the plant leaves through stomata or epidermal adsorption and are transported to various plant parts via the vascular system and symplastic pathways [53]. Consequently, the inactivation activity of the prepared CDNPs reflects the direct activity against AMV particles through binding to RNA, resulting in replication inhibition [54,55]. On the other hand, CDNPs may be acting as elicitor molecules, activating plant immunity, and triggering the hypersensitivity response through increased antioxidant and defensive enzyme activity [56].

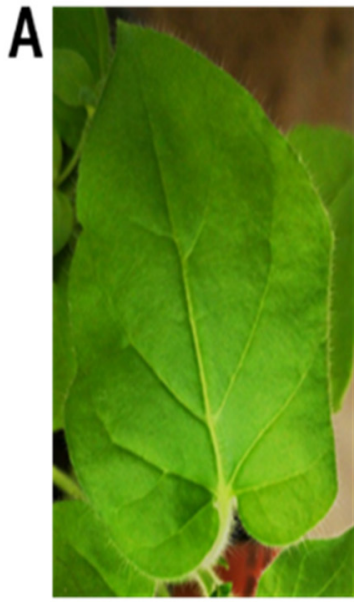

Healthy (Control)

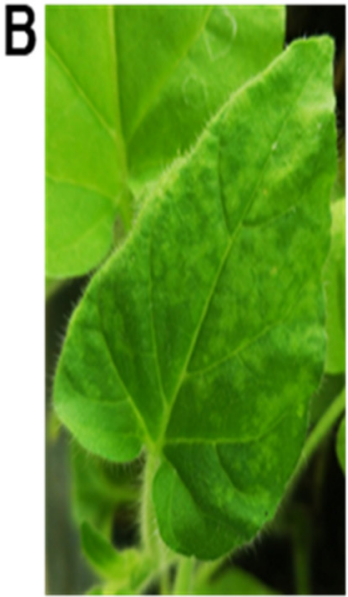

AMV-infected

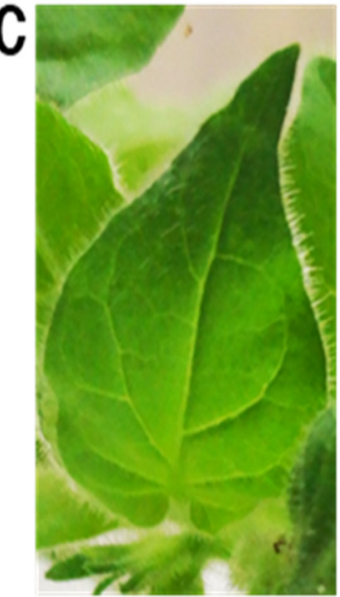

Protective

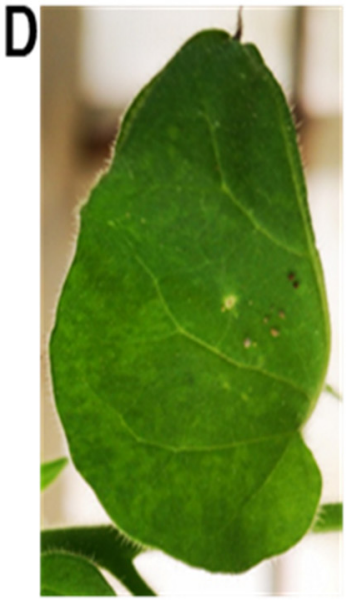

Curative

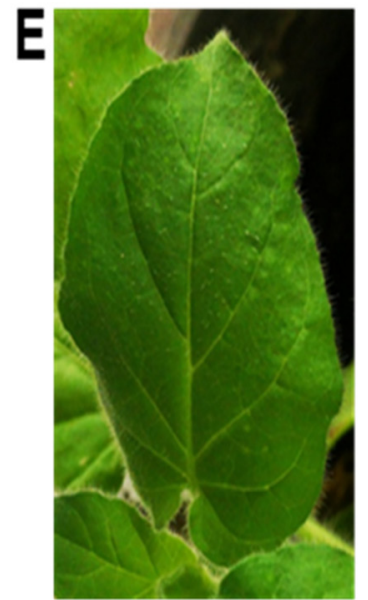

Inactivating

Figure 4. Effect of chitosan/dextran nanoparticles (CDNPs) on the disease symptoms development on N. glutinosa leaves infected with AMV at 20 days post-inoculation. (A) Mock-inoculated control plants, (B) AMV-inoculated control plants, (C) plants treated with CDNPs $\left(100 \mu \mathrm{g} \mathrm{mL}^{-1}\right) 24 \mathrm{~h}$ before inoculation of AMV (protective treatment), (D) plants treated with CDNPs $\left(100 \mu \mathrm{g} \mathrm{mL}^{-1}\right) 24 \mathrm{~h}$ after inoculation of AMV (curative treatment), (E) plant treated with a mixture of CDNPs with the same amount of purified TMV and incubated for $1 \mathrm{~h}$ (inactivity treatment).

The ELISA test was performed on all the treatments, and the results were consistent with the appearance of symptoms in terms of the highest concentration and the lowest and free of the virus. The highest viral concentration level was observed in AMV-inoculated con- 
trol plants (non-CDNPs treated) with an ELISA value of 0.991, while the mock-inoculated control plants showed a 0.0585 ELISA value (Figure 5A). The CDNPs-treated plants exhibited ELISA values of $0.293,0.380$, and 0.083 for curative, protective, and inactivating treatments, respectively (Figure 5A). The ELISA reactions revealed that the inactivating treatment was the most effective CDNPs treatment, followed by protective and curative treatments. The considerable reduction in AMV accumulation level in N. glutinosa leaves by $100 \%, 70.43 \%$, and $61.65 \%$ in inactivating, protective, and curative treatments, respectively, reflected the anti-AMV activity of the prepared CDNPs nanoparticles. In this context, foliar application and treatment of tomato plants with ZnO NPs and Ag NPs reduced viral accumulation levels inside plant tissues and decreased disease severity [26,57]. In agreement with our results, chitosan nanoparticles might attach to virus particles, inhibit nucleic acid replication inside infected cells, as well as boost plant immunity and antioxidant defense systems [51,58]. Electron microscope examination revealed that the TMV particles were directly affected by nanoparticles, resulting in decreased viral particles, and the majority of them twisted together and tied into a bundle, leading to virus structure rupture [55,59]. In agreement with our results, the DAS-ELISA showed the efficacy of chitosan to control CMV, PVX, and TMV infections $[51,58,60]$. The authors suggested that chitosan increased plant resistance through enhancing ribonuclease activity and callose deposition as well as increasing the activity of hydrolases (proteases and RNases). Consequently, the data obtained support the beneficial effects of CDNPs as plant viral inhibitors as well as plant resistance inducers.
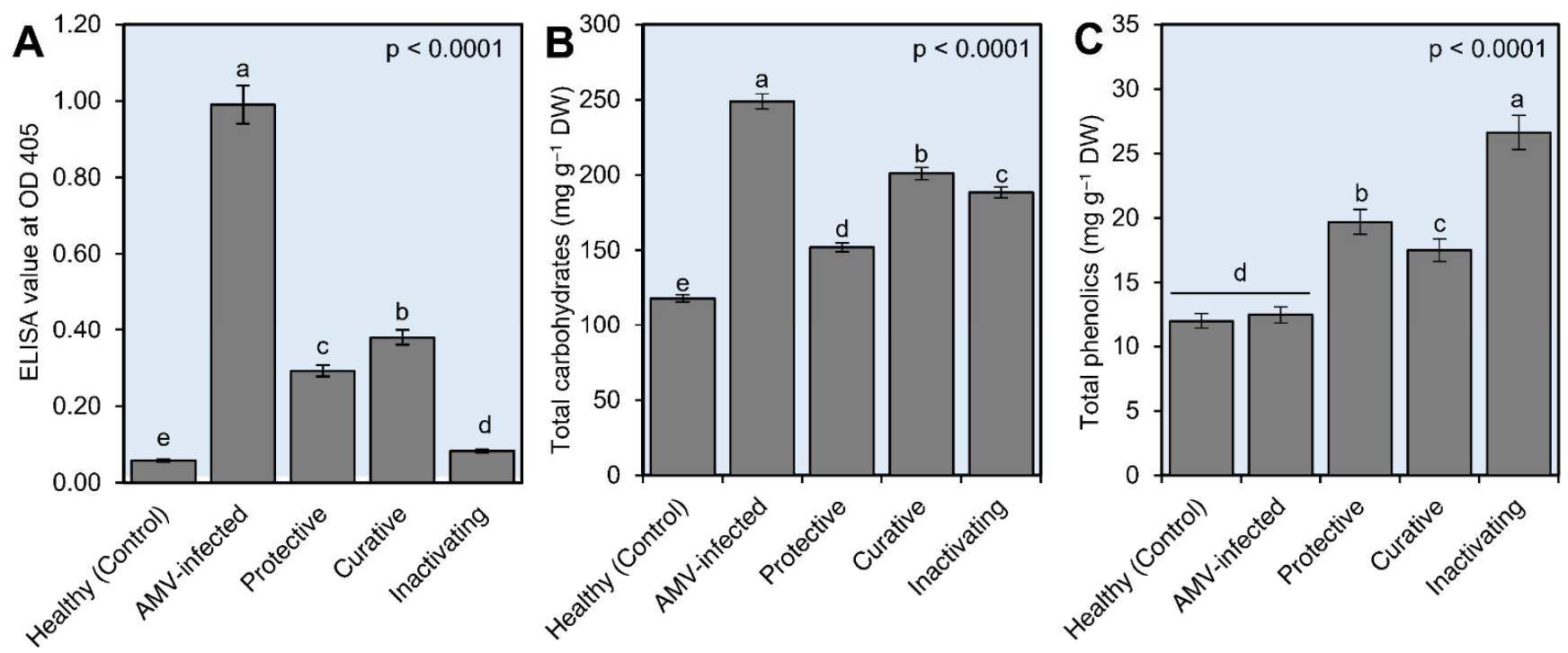

Figure 5. (A) A histogram showing the accumulation level of AMV in AMV-infected N. glutinosa plants at 22 dpi of different treatments. (B) Effect of chitosan/dextran nanoparticles (CDNPs) on total carbohydrates and total phenolics (C) of AMV-infected N. glutinosa plants at 22 dpi of different treatments. Data presented are means \pm standard deviation (mean $\pm \mathrm{SD}$ ) of three biological replicates. Different letters indicate statistically significant differences among treatments according to Tukey's honestly significant difference test $(p<0.05)$.

\subsubsection{Determination of Total Soluble Carbohydrates and Total Phenolic Contents}

The plant accumulates soluble carbohydrates throughout development and maturation, which are involved in most basic physiological processes and have important roles in seed germination and seed desiccation tolerance [61]. Carbohydrate changes directly correlate with physiological processes such as photosynthesis, transpiration, and respiration [62]. Stress conditions alter carbohydrate accumulation and distribution in plants [63]. The present study clearly showed that CDNPs treatments generally induced a significant increase in total soluble carbohydrates. The highest total soluble carbohydrate (747 $\mathrm{mg} \mathrm{g}^{-1} \mathrm{DM}$ ) was reported in the AMV-inoculated control plants, followed by curative, 
inactivating, and protective treatments with 603,565 , and $456 \mathrm{mg} \mathrm{g}^{-1} \mathrm{DM}$, respectively. Moreover, the mock-inoculated control plants exhibited $354 \mathrm{mg} \mathrm{g}^{-1} \mathrm{DM}$ (Figure 5B). Similar findings were reported by Hoekstra et al. [64], who observed that the soluble carbohydrates accumulated in accordance with plant abiotic stress. Although some plant viruses upon infection have no effect on carbohydrate synthesis or its translocation in the leaf tissues, other viruses may modulate it [65]. The accumulation of carbohydrates (starches) has indeed been recognized to anticipate the appearance of virus symptoms in plants infected with ZYMV [65]. Arias et al. [66] reported similar results in sunflower plants infected with the sunflower chlorotic mottle virus. In addition, fructose and glucose sugars were greatly increased in leaves infected by the beet yellows virus [67]. In our study, we hypothesized that the CDNPs could alter the effects of viral infection on N. glutinosa by decreasing the total soluble carbohydrate content accumulation.

For total phenolic contents (TPC) estimation, the highest value $\left(79.9 \mathrm{mg} \mathrm{g}^{-1}\right)$ was reported in the inactivating treatment, while the lowest $\left(36 \mathrm{mg} \mathrm{g}^{-1} \mathrm{DM}\right)$ was reported in the mock-inoculated control treatment. Additionally, both protective and curative treatments showed increases in TPC with 59.1 and $52.5 \mathrm{mg} \mathrm{g}^{-1} \mathrm{DM}$, respectively, compared with AMV-inoculated control plants ( $37.7 \mathrm{mg} \mathrm{g}^{-1} \mathrm{DM}$; Figure 5C). In addition, data analysis revealed an increase in TPC following plant infection, which aligned with Khalid et al. [68], who found that phenolics were boosted in diverse plants following pathogen infection. Increases in plant metabolites such as phenols have been demonstrated to play a major part in the plethora of host-pathogen interactions, disease progression, and infected plant defensive system responses [69-72]. Based on the findings, we believe that the synthesized CDNPs have substantial antiviral efficacy that could be used in biocontrol agents as elicitor molecules to trigger SAR and plant viral disease management.

\subsubsection{Transcriptional Levels of the Defense-Related Genes}

The transcription levels of three $N$. glutinosa defense-related genes, including peroxidase $(P O D)$, pathogenesis-related protein $1(P R-1)$, and phenylalanine ammonia-lyase $(P A L)$, were investigated at different time intervals of $3,6,10,15$, and $20 \mathrm{dpi}$.

\section{Peroxidase (POD)}

It is well established that antioxidant enzymes play critical roles in preventing the serious consequences of reactive oxygen species (ROS) generated by viral infections, including plant cell damage [73,74]. For example, $P O D$ enzymes can remove $\mathrm{H}_{2} \mathrm{O}_{2}$, reduce free radicals, and protect the cytoplasmic membrane [75]. Compared to mock-inoculated control plants in the current study, the transcripts of $P O D$ were significantly induced after challenging $N$. glutinosa plants with CDNPs at various time intervals in different treatments (Figure 6A). Generally, the inactivating treatment had the highest POD expression levels throughout the experiment. At $3 \mathrm{dpi}$, the inactivating treatment showed the highest relative expression level (4.04-fold) followed by protective treatment (2.89-fold) and curative treatment with a relative expression level of 2.37 -fold higher than mock-inoculated control (Figure 6A). At 6 dpi, the most outstanding relative transcriptional level (3.60-fold) was reported in the inactivating treatment, while protective and curative treatments showed 2.72- and 2.69-fold greater changes, respectively, than mock-inoculated control. At all studied times, 3, 6, 10, 15, and $20 \mathrm{dpi}$, no significant differences were reported between the AMV-inoculated control plants and mock-inoculated control plants (Figure 6A). It was stated that the induction and increasing activity of $P O D$ were associated with the increasing chlorophyll content and enhanced plant resistance against pathogens, including Mungbean yellow mosaic virus and TMV [76,77]. Moreover, POD was reported as a key player in plant defense responses against viral infection such as Pepper yellow mosaic virus in chili pepper (Capsicum baccatum var. pendulum) [78], cowpea chlorotic mottle virus in soybean (Glycine max) [79], and Tobacco mosaic virus (TMV) in tobacco plants [80]. In addition, foliar application of chitosan nanoparticles significantly elevated plant defense enzymes [23]. It was reported that chitosan nanoparticles can act as an immunological modulator in 
tea and finger millet plants by inducing antioxidant/defense enzyme activity [19,81]. At $10 \mathrm{dpi}$, the relative expression levels of protective, curative, and inactivating treatments were 2.40-, 2.26-, and 3.48-fold higher than mock-inoculated control, where at $15 \mathrm{dpi}$, they recorded 2.23-, 2.49-, and 2.52-fold changes, respectively, greater than mock-inoculated control (Figure 6A). At $20 \mathrm{dpi}$, the three treatments protective, curative, and inactivating exhibited transcriptional levels of 2.29-, 2.35-, and 2.32-fold change, respectively, with no significant change between them (Figure 6A).
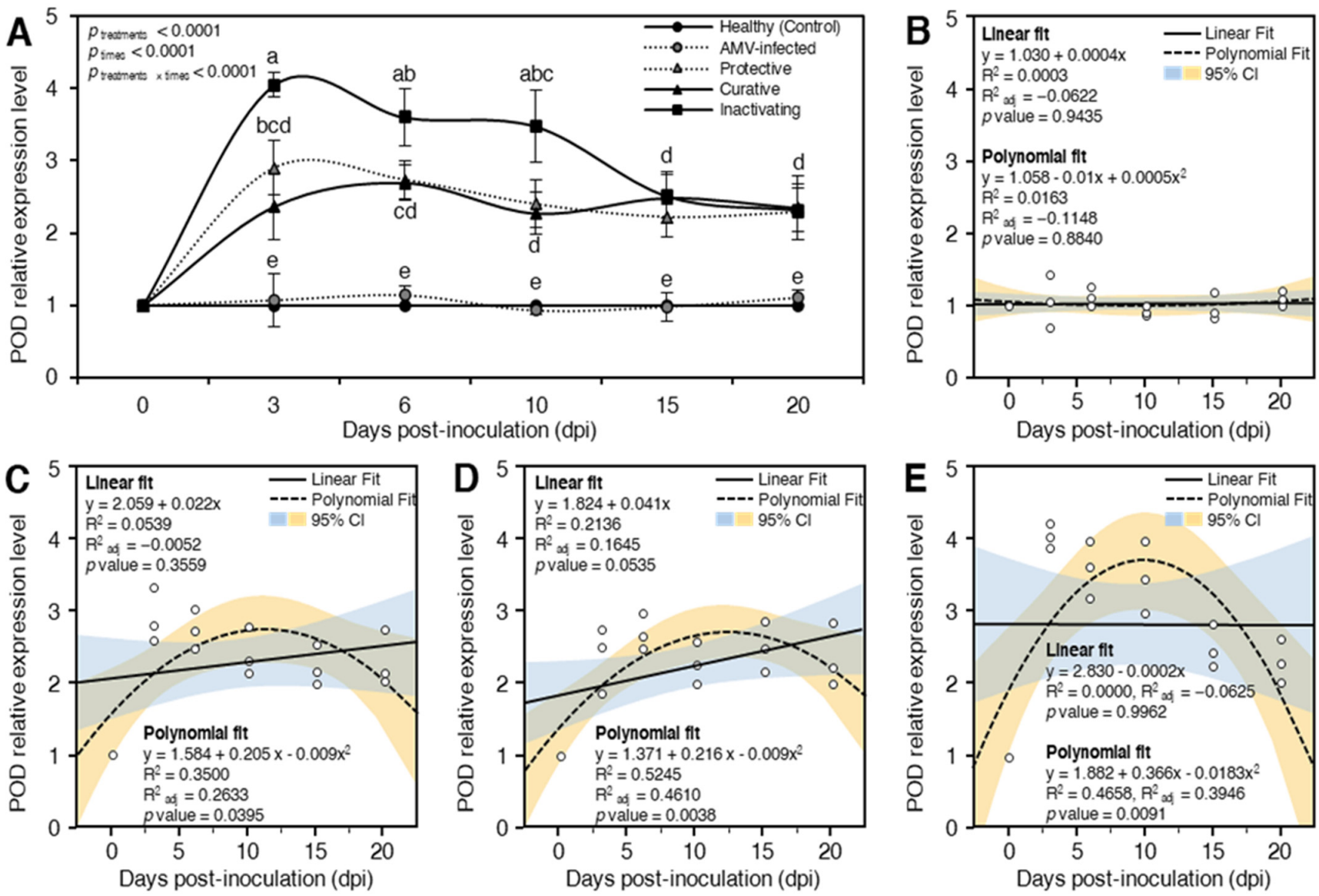

Figure 6. Effect of chitosan/dextran nanoparticles (CDNPs) on the relative expression level of peroxidase (POD) in AMVinfected N. glutinosa plants at 3, 6, 10, 15, and 20 dpi. (A) POD relative expression levels of different treatments at 3, 6, 10,15 , and 20 dpi. Data presented are means \pm standard deviation (mean \pm SD) of three biological replicates. Different letters indicate statistically significant differences among treatments according to Tukey's honestly significant difference test $\left(p_{\text {time }} \times\right.$ treatment $\left.<0.05\right)$. (B-E) Simple linear regression $(\mathrm{SLR})$ and quadratic polynomial regression analysis between $P O D$ relative expression and time post-inoculation of AMV-infected, protective-treated, curative-treated, and inactivating-treated plants, respectively. Open small circles present the row data $(n=3)$, solid lines present the SLR line, and polynomial regression models are presented as dashed-line. The $95 \%$ confidence intervals for the estimated regression are blue- and yellow-shaded. Regression equations, $\mathrm{R}^{2}, \mathrm{R}^{2}$ adj, and $p$-value based on the $\mathrm{F}$ test $(p<0.05)$ were also obtained and presented within the graph.

Moreover, to better understand the relationship between $P O D$ relative expression and time post-inoculation, data were fitted using a simple linear regression (SLR) model. Although the SLR showed no correlation between POD relative expression of AMV-infected control treatment and time post inoculation $\left(\mathrm{R}^{2}=0.0003\right.$ and $p=0.9435$; Figure 6B), it showed a slight correlation between them in protective treatment $\left(R^{2}=0.0539\right.$ and $p=0.3559$; Figure 6C). Additionally, the correlation between $P O D$ expression and time post inoculation was strengthened when $N$. glutinosa plants were treated with curative treatment $\left(R^{2}=0.2136\right.$ and $p=0.0535$; Figure $\left.6 \mathrm{D}\right)$, but not in the inactivating treatment $\left(\mathrm{R}^{2}=0.0000\right.$ and $p=0.9962$; Figure 6E). In the current study, all CDNPs treatments sub- 
stantially increased the expression of $P O D$; however, only protective and curative, but not inactivating, treatments showed a positive relationship with time post-inoculation with its highest peak at 3 dpi. Furthermore, due to the nonlinear phenomena between POD expression and time post inoculation, data were fitted with a second-degree polynomial regression model under different CDNPs treatments (Figure 6B-E). In AMV-inoculated control plants, polynomial regression between $P O D$ expression and time post inoculation was very weak $\left(R^{2}=0.0163\right.$ and $p=0.8840$; Figure $\left.6 \mathrm{~B}\right)$. However, the relationship between them followed a positive and quadratic model when $N$. glutinosa plants were treated with protective $\left(\mathrm{R}^{2}=0.3500\right.$ and $p=0.0395$; Figure $\left.6 \mathrm{C}\right)$, curative $\left(\mathrm{R}^{2}=0.5245\right.$ and $p=0.0038$; Figure $6 \mathrm{D})$, or inactivating treatment $\left(\mathrm{R}^{2}=0.4658\right.$ and $p$ value $=0.0091$; Figure $\left.6 \mathrm{E}\right)$. Previous studies showed that chitosan induced the POD activity in Pinus koraiensis seedlings to its highest peak at 2 dpi [82]. Nevertheless, POD activity reached its highest levels at 9 hpi in downy mildew-infected pearl millet plants after the treatment with chitosan nanoparticles [83]. It is worth mentioning that the AMV-infected plants showed no increase in the transcript levels of POD compared with the mock-inoculated control. However, POD was upregulated only when plants were treated with CDNPs. Collectively, these findings indicate the priming effect after the application of CDNPs.

The obtained results showed that the prepared CDNPs might reduce ROS adverse effects on plant cell membranes by activating ROS scavenging enzymes. Therefore, the antioxidant properties of the prepared CDNPs can putatively increase resistance to oxidative stress in plant tissues. These properties are mostly owing to their abundance of active hydroxyl and amino groups, which can interact with ROS to generate stable and relatively non-toxic macromolecular radicals [84]. The obtained results agree with Chandra et al. [19], who reported that the application of chitosan or chitosan nanoparticles can potentially provide protection to the plants against different oxidative stresses through activating antioxidant enzymes that result in ROS inhibition. Furthermore, Choudhary et al. [85] suggested that increased $S O D$ and $P O D$ activities following nanoparticle application may be responsible for scavenging ROS to protect plants from oxidative stress during pathogen invasion.

Pathogenesis-Related Protein 1 (PR-1)

Salicylic acid (SA) is an important signal plant phytohormone molecule of SAR [86]. Furthermore, $P R-1$ is a marker of the SA signaling pathway that inhibits programmed cell death, stimulates plant immunity, regulates SAR in plants, and may serve as a marker for early plant defense responses $[87,88]$. The accumulation and expression of $P R-1$ is associated with the activation of SA in response to pathogens [89]. In the present study, both treatments $\left(p_{\text {treatments }}<0.0001\right)$ and time post-inoculation $\left(p_{\text {times }}<0.0001\right)$ significantly affected the relative expression levels of $P R-1$. The highest expression level of $P R-1$ was reported in the inactivating treatment followed by protective treatment and curative treatment compared to mock-inoculated control and AMV-inoculated control plants at all tested time intervals (Figure 7A). At 3 dpi, the PR-1 was significantly $\left(p_{\text {treatments }} \times\right.$ times $<0.0001$ ) up-regulated in protective and inactivating only with relative expression levels 2.09- and 7.16-fold higher, respectively, than the mock-inoculated control. The two treatments (AMVinoculated control and curative) did not differ significantly ( $p_{\text {treatments }} \times$ times $\left.<0.0001\right)$ when compared to the mock-inoculated control (Figure 7A). These results suggest that the early induction of $P R-1$, which is associated with the accumulation of SA content, in protective and inactivating plants reflects the ability of CDNPs to develop plant SAR [19]. At $6 \mathrm{dpi}$, the expression levels of protective and inactivating continued to increase, while AMV-inoculated control and curative plants exhibited slight induction with relative transcriptional levels 1.31- and 1.80-fold greater than mock-inoculated control. Compared to the expression profile at $6 \mathrm{dpi}$, all transcriptional levels of all treatments decreased, apart from inactivating treatment, which showed an 8.36-fold increase in expression at $10 \mathrm{dpi}$ (Figure 7A). This drop in the relative expression levels might be due to the increasing suppressor activity of AMV [31]. At $15 \mathrm{dpi}$, the highest expression levels (9.44-fold) were shown in inactivation followed by protection (5.84-fold), curative (4.45-fold), and AMV- 
inoculated control plants (1.83-fold) higher than mock-inoculated control (Figure 7A). At $20 \mathrm{dpi}$, the expression levels of protective and inactivating continued to increase, reaching their maximum levels, while AMV-inoculated control and curative plants exhibited a slight reduction in their relative transcriptional levels (Figure 7).
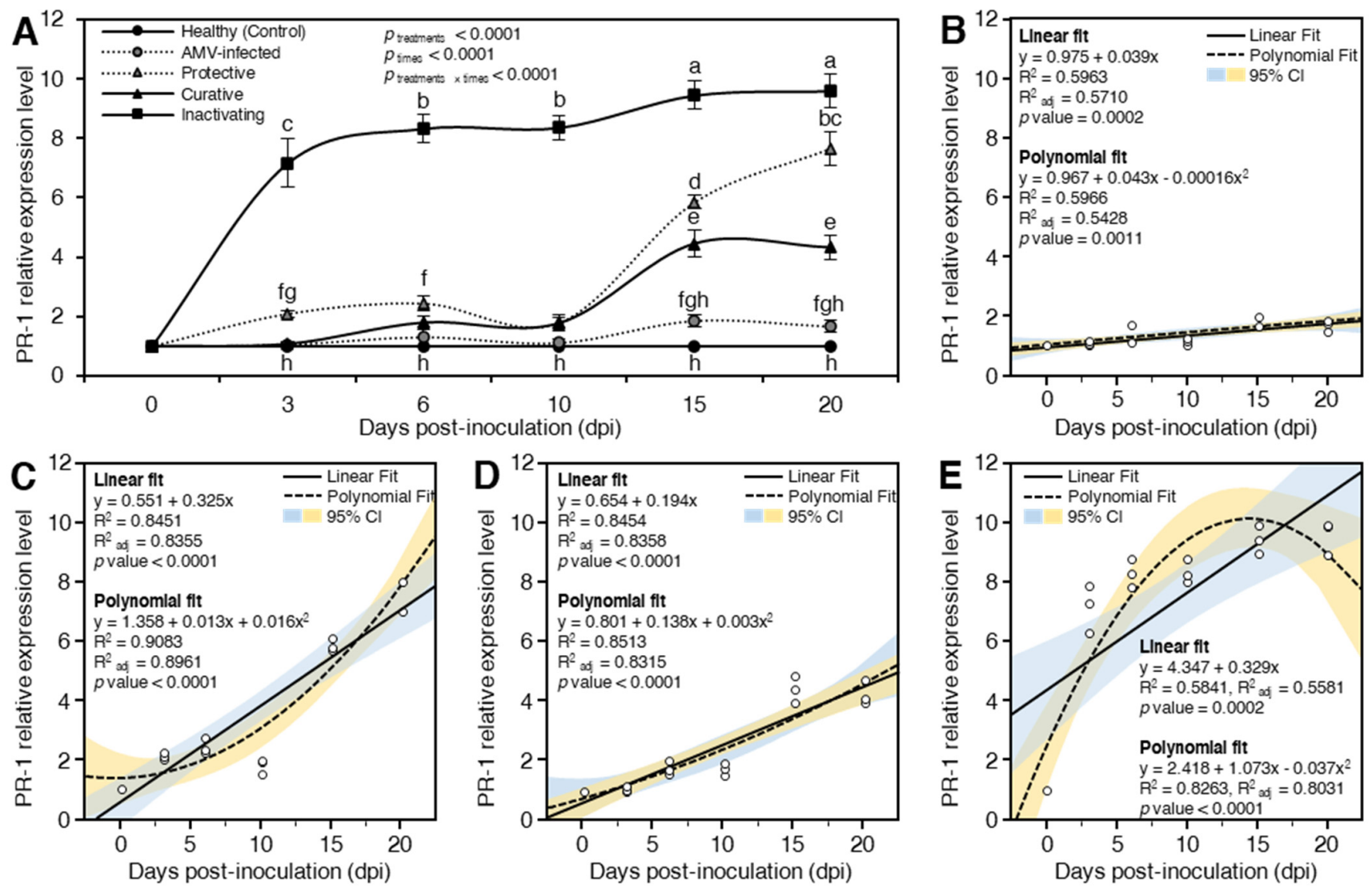

Figure 7. Effect of chitosan/dextran nanoparticles (CDNPs) on the relative expression level of Pathogenesis-related protein 1 (PR-1) in AMV-infected N. glutinosa plants at 3, 6, 10, 15, and 20 dpi. (A) PR-1 relative expression levels of different treatments at $3,6,10,15$, and 20 dpi. Data presented are means \pm standard deviation (mean \pm SD) of three biological replicates. Different letters indicate statistically significant differences among treatments according to Tukey's honestly significant difference test $\left(p_{\text {time }} \times\right.$ treatment $\left.<0.05\right)$. (B-E) Simple linear regression (SLR) and quadratic polynomial regression analysis between $P R-1$ relative expression and time post-inoculation of AMV-infected, protective-treated, curative-treated, and inactivating-treated plants, respectively. Open small circles present the row data $(n=3)$, solid lines present the SLR line, while polynomial regression models are presented as dashed-line. The $95 \%$ confidence intervals for the estimated regression are blue- and yellow-shaded. Regression equations, $\mathrm{R}^{2}, \mathrm{R}^{2}$ adj, and $p$-value based on the $\mathrm{F}$ test $(p<0.05)$ were also obtained and presented within the graph.

To better understand the relationship between relative expression of $P R-1$ and time post-inoculation, data were fitted using an SLR model. Although the relative expression of $P R-1$ was positively correlated with time post-inoculation in AMV-inoculated control plants, their relationship was weak $\left(R^{2}=0.5963\right.$ and $p=0.0002$; Figure $\left.7 \mathrm{~B}\right)$. Nevertheless, the protective $\left(R^{2}=0.8451\right.$ and $p<0.0001$; Figure $\left.7 C\right)$ and curative $\left(R^{2}=0.8454\right.$ and $p<0.0001$; Figure 7D) significantly strengthened the correlation between relative expression of $P R-1$ and time post-inoculation, even better than the inactivating treatment $\left(R^{2}=0.5841\right.$ and $p=0.0002$; Figure 7E). In this study, relative expression of $P R-1$ was positively correlated with time post-inoculation in AMV-infected plants. Nevertheless, CDNPs application significantly strengthened the correlation between relative expression of $P R-1$ and time post-inoculation. It is worth mentioning that inactivating treatment had the highest PR1 levels over the time course. This might be due to the positive effect of CDNPs on the AMV particles, resulting in completely inactivated viral activity. Moreover, because of 
the nonlinear relationship between relative expression of $P R-1$ and time post-inoculation, data were fitted using a second-degree polynomial regression model and presented in Figure 7B-E. It is worth mentioning that the relationship between relative expression of $P R-$ 1 and time post-inoculation at different treatments followed a positive and quadratic model. The relationship between exogenous $P R-1$ and time post-inoculation of AMV-inoculated control plants is described by the equation $\left(\mathrm{R}^{2}=0.5966\right.$ and $p=0.0011$; Figure 7B), while for protective-treated plants is described by the equation $\left(\mathrm{R}^{2}=0.9083\right.$ and $p<0.0001$; Figure 7C), for curative-treated plants $\left(R^{2}=0.8513\right.$ and $p<0.0001$; Figure 7D), and for inactivating-treated plants is described by $\left(R^{2}=0.8263\right.$ and $p<0.0001$; Figure 7E).

The transcriptional obtained results suggest that the application of CDNPs can be used as an eco-friendly approach to trigger plant immune defense systems that may result in SA content accumulation and SAR activation. It is well proven that PR genes are key components of the plant's innate immune system, particularly SAR, and are commonly employed as diagnostic molecular markers for defense signaling pathways [90]. Thus, the overexpression of $P R-1$, either separately or in combination, can significantly increase plant defense against AMV infection. Previous studies have been demonstrated that overexpression of $P R-1$ protein in tobacco plants increased resistance against TMV [91]. Moreover, the application of chitosan nanoparticles $(0.1, w / v)$ was associated with the induction of several defense-related enzymes, including chitinase, protease inhibitors, $P O D$, and $P P O$ in finger millet plant leaves, which ended with boosting innate immunity [23].

\section{Phenylalanine Ammonia-Lyase (PAL)}

Besides its role in SA biosynthesis, PAL is the key enzyme of the phenylpropanoid pathway, which connects primary and secondary metabolism by converting L-phenylalanine to ammonia and trans-cinnamic acid [92,93]. In higher plants, SA is synthesized from chorismate using isochorismate synthase [94] or from L-phenylalanine by the activity of $P A L[95,96]$, which is more common. Moreover, it was stressed that the importance of phenolic compounds in disease resistance, as well as their accumulation through the phenylpropanoid pathway as a result of different elicitor applications, has been previously reported [11,19]. Like the $P R-1$ expression profile, the highest transcriptional levels of $P A L$ were observed in inactivating ( $\left.p_{\text {treatments }}<0.0001\right)$ treatment, followed by protective and curative treatments at all dpi (Figure $8 \mathrm{~A}$ ). Likewise, time post-inoculation significantly affected the PAL expression levels in different treatments $\left(p_{\text {time }}<0.0001\right)$. For instance, at $3 \mathrm{dpi}$, it was observed that the foliar application of CDNPs rapidly induced PAL with significant $\left(p_{\text {treatments }} \times\right.$ times $\left.<0.0001\right)$ relative expression levels 1.88-, 2.41-, and 4.64-fold higher than the mock-inoculated control in curative, protective, and inactivating treatments, respectively (Figure $8 \mathrm{~A}$ ). On the other hand, no significant difference was observed in $P A L$ expression levels in AMV-inoculated control plants compared to mock-inoculated control at the same time. At 6 and $10 \mathrm{dpi}$, inactivating treatment plants exhibited dramatically increased PAL transcripts, while the three treatments (AMV-inoculated control, protective, and curative) showed dramatically decreased $P A L$ expression levels at the same two-time intervals (Figure 8A). The AMV-inoculated control plants showed significant down-regulation with an expression level 0.82- and 0.87-fold lower than mock-inoculated control at 6 and $10 \mathrm{dpi}$, respectively. After that, the accumulation of $P A L$ increased for all treatments, reaching a maximum at $20 \mathrm{dpi}$ (Figure $8 \mathrm{~A}$ ). At $20 \mathrm{dpi}$, the relative transcriptional levels were 1.75-, 4.03-, 6.43-, and 8.62-fold higher than mock-inoculated control in AMV-inoculated control, curative, protective, and inactivating treatments, respectively. In this regard, the antiviral activities of CDNPs have been ruled out in AMV-inoculated control N. glutinosa leaves, and the inhibitory effects of treatment (protective, curative, and inactivating) were attributed to the elicitation of the plant defense mechanisms and direct suppression of viral replication $[23,51,56,58]$. In agreement with these findings, previous studies showed that although the Cucumber mosaic virus did not significantly affect the expression levels of $P A L$, chitosan reduced the viral load and up-regulated $P A L$ expression in infected tomato plants [51]. Nevertheless, the expression profile of $P A L$ usually depends 
on the host, pathogen, and maybe some other factors. For instance, PAL reached its highest activity at 2 dpi in Pinus koraiensis seedlings treated with $100 \mathrm{mg} \mathrm{L}^{-1}$ chitosan [82], while it peaked at $6 \mathrm{hpi}$ in downy mildew-infected pearl millet plants after the treatment with chitosan nanoparticles [83].
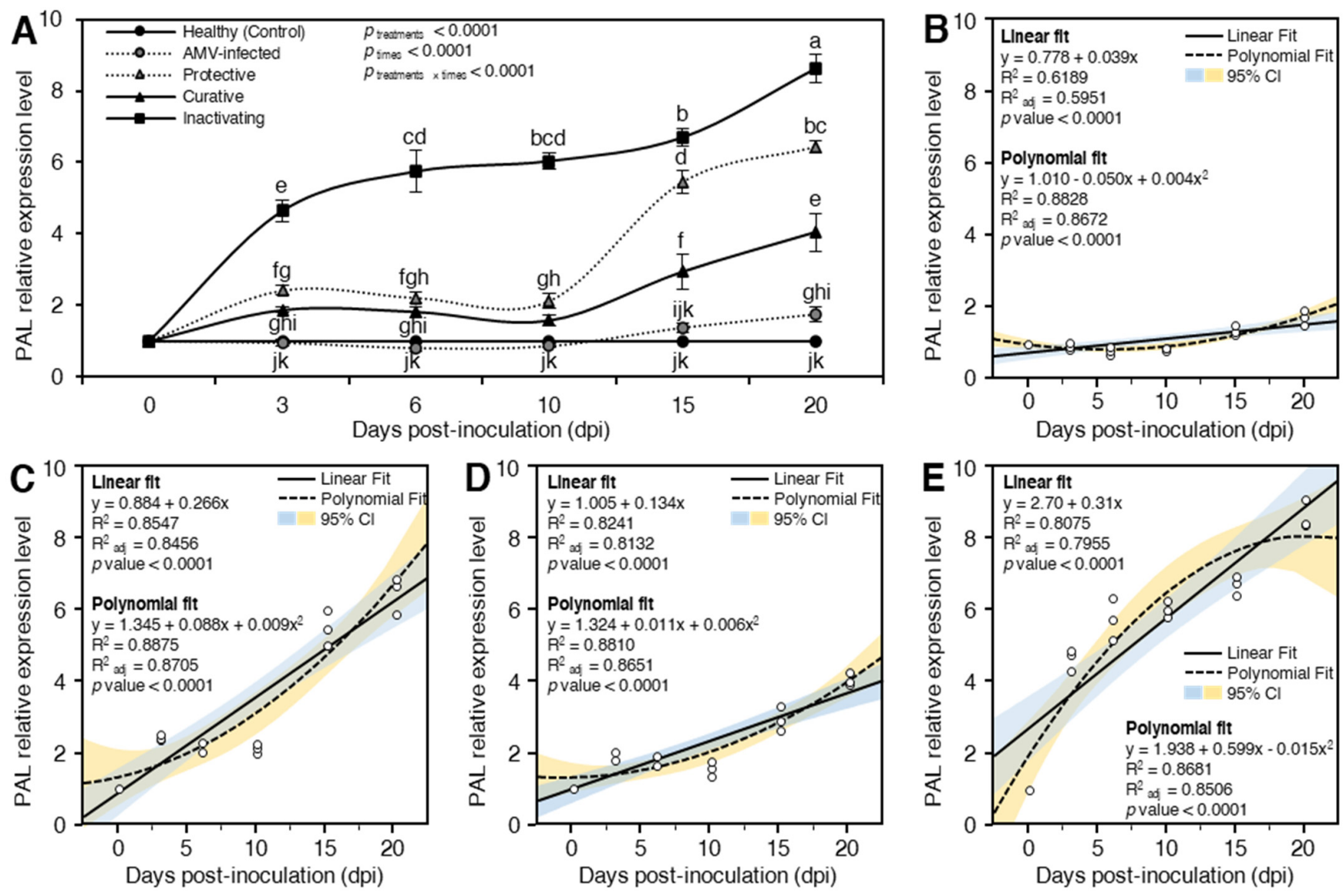

Figure 8. Effect of chitosan/dextran nanoparticles (CDNPs) on the relative expression level of phenylalanine ammonia-lyase $(P A L)$ in AMV-infected N. glutinosa plants at 3, 6, 10, 15, and 20 dpi. (A) PAL relative expression levels of different treatments at $3,6,10,15$, and $20 \mathrm{dpi}$. Data presented are means \pm standard deviation (mean \pm SD) of three biological replicates. Different letters indicate statistically significant differences among treatments according to Tukey's honestly significant difference test $\left(p_{\text {time }} \times\right.$ treatment $\left.<0.05\right)$. (B-E) Simple linear regression (SLR) and quadratic polynomial regression analysis between PAL relative expression and time post-inoculation of AMV-infected, protective-treated, curative-treated, and inactivating-treated plants, respectively. Open small circles present the row data $(n=3)$, solid lines present the SLR line, while polynomial regression models are presented as dashed lines. The $95 \%$ confidence intervals for the estimated regression are blue- and yellow-shaded. Regression equations, $\mathrm{R}^{2}, \mathrm{R}^{2}$ adj, and $p$-value based on the $\mathrm{F}$ test $(p<0.05)$ were also obtained and presented within the graph.

Additionally, the relationship between relative expression of PAL and time post inoculation was fitted using an SLR model. Although the SLR showed that PAL expression was weakly correlated with time post inoculation in AMV-inoculated control plants $\left(\mathrm{R}^{2}=0.6189\right.$ and $p<0.0001$; Figure 8B), CDNPs application significantly strengthened the positive correlation between $P A L$ expression and time post inoculation in protective-treated $\left(\mathrm{R}^{2}=0.8547\right.$ and $p<0.0001$; Figure 8C), curative-treated $\left(\mathrm{R}^{2}=0.8241\right.$ and $p<0.0001$; Figure 8D), and inactivating-treated plants $\left(\mathrm{R}^{2}=0.8075\right.$ and $p<0.0001$; Figure $\left.8 \mathrm{E}\right)$. Our findings showed that $P A L$ expression levels were slightly increased over the time course in AMV-infected plants compared with the healthy control. However, PAL gradually upregulated upon CDNPs application throughout the experiment (up to $20 \mathrm{dpi}$ ). Moreover, PAL expression levels were in a tandem match with the expression patterns of PR1 over the time course of $20 \mathrm{dpi}$. Furthermore, to better understand the nonlinear phenomena between relative expression of 
$P A L$ and time post inoculation, data were fitted with a second-degree polynomial regression model. Interestingly, the relationship between $P A L$ expression and time post inoculation followed a positive and quadratic model in all tested treatments including AMV-inoculated control $\left(\mathbf{R}^{2}=0.8828\right.$ and $p<0.0001$; Figure $\left.8 \mathrm{~B}\right)$, protective-treated $\left(\mathbf{R}^{2}=0.8875\right.$ and $p<0.0001$; Figure $8 C)$, curative-treated $\left(R^{2}=0.8810\right.$ and $p<0.0001$; Figure $\left.8 D\right)$, and inactivating-treated plants $\left(R^{2}=0.8681\right.$ and $p<0.0001$; Figure $\left.8 \mathrm{E}\right)$.

The function of phenolic compounds in disease resistance, as well as their accumulation by the phenylpropanoid pathway as a result of various elicitor treatments, has previously been described. In the present study, the N. glutinosa plants showed a higher accumulation of phenolic compounds than mock-inoculated control and AMV-inoculated control plants, which could be a direct result of the induction and upregulation of PAL activity in the CDNPs treated plants. Consequently, CDNPs may work as an elicitor molecule that induces and stimulates the plant immune defense system, possibly inducing the early SA signaling pathway resulting in SAR activation [97]. Such a result is in accordance with Mejía-Teniente et al. [74], who observed that chitosan-treated Capsicum annuum plants exhibited increasing PAL expression. Moreover, Chandra et al. [19] reported that the treatment of tea leaves with chitosan nanoparticles was associated with an up-regulation of $P A L$ activity that resulted in a higher accumulation of phenolic compounds. These data support the accumulation of more flavonoids in the chitosan-treated leaves, as well as a secondary defensive induction in the treated plants [19]. The intrinsic positive charge of chitosan-based nanoparticles can interact with the negative charge found on the cell membrane and mucosal surfaces, resulting in mucoadhesive characteristics. Moreover, the antiviral activity of nanoparticles may be due to the inactivation of viral multiplication and the activation of plant defense systems that lead to plant immunity [55].

In general, regression-based statistical modeling has been introduced previously in the biomedical field to identify the relationship between differentially expressed genes in time-course studies [98]. Regression-based prediction of gene expression patterns could be achieved using linear regression [99,100] and/or logistic regression [101] models. Moreover, polynomial regression methods, particularly quadratic regression analysis, are helpful in the identification of differentially expressed genes in a non-cyclic short-time course [102]. In the current study, we used simple linear (fitting a straight line to the observed data) and quadratic-polynomial (fitting a curved line to the observed data) regression modeling to better understand the quantitative relationship between gene expression and short-time course. Regression models of $P O D, P R-1$, and $P A L$ showed that all CDNPs treatments strengthened the positive relationship between gene expression and time-post inoculation as expressed by higher coefficients of determination (R2). In the activating treatment (premixing of viral particles with CDNPs for $1 \mathrm{~h}$ before inoculation), the absence of viral symptoms on the inoculated plants, negative ELISA results, and the highest induction of the three tested genes at all study times suggested that the inactivating treatment completely disrupted viral particles and inhibited replication. As a result, the inactivating treatment plants exhibited the highest transcriptional levels. On the other hand, the regression models suggested that the both protective and curative treatments showed a stronger correlation with time-post inoculation for POD, $P R-1$, and $P A L$. Collectively, our findings suggest that the protective and curative treatments, particularly protective, might be good for long-term solutions. However, more research into its ability under different combinations of host-pathogen interaction, as well as long-term (more than 20 days) studies, is needed to investigate the potential mechanisms and biological phenomena of differentially expressed genes over time.

\section{Conclusions}

In the current study, the antiviral activities of synthesized chitosan/dextran nanoparticles (CDNPs) on N. glutinosa plants were evaluated. Scanning electron microscope analysis revealed that the synthesized CDNPs were uniform, regular sphere shapes. In addition, particle size analysis reported that CDNPs were distributed in a range of 20-160 nm with 
an average diameter of $91.68 \mathrm{~nm}$. Under greenhouse conditions, the foliar application of CDNPs $\left(100 \mu \mathrm{g} \mathrm{mL}^{-1}\right)$ decreased viral disease severity, induced systemic acquired resistance (SAR), reduced AMV accumulation levels, and up-regulated the transcriptional levels of $P O D, P R-1$, and $P A L$ genes. In light of the information gathered, we propose that the potential application of CDNPs could be a long-term and financially viable strategy for obtaining nutritional security.

Author Contributions: Conceptualization, A.A. and S.I.B.; methodology, A.A., S.H.Q., M.A.A.-R.A.-S., A.M.K., H.A.Y., Y.N. and S.I.B.; software, A.A. and Y.N.; formal analysis, A.A., S.I.B. and Y.N.; investigation, A.A., M.A.A.-R.A.-S., A.M.K., H.A.Y. and S.I.B.; writing-original draft preparation, A.A., S.I.B., Y.N. and M.A.A.-R.A.-S.; writing-review and editing, A.A., S.I.B. and Y.N. All authors have read and agreed to the published version of the manuscript.

Funding: This research received no external funding.

Institutional Review Board Statement: Not applicable.

Informed Consent Statement: Not applicable.

Data Availability Statement: All data reported here are available from the authors upon request.

Acknowledgments: A.A., Y.N., and S.I.B. would like to extend their appreciation to the City of Scientific Research and Technological Applications (SRTA-City), Graduate Student and Research Affairs Sector of Tanta University, and University of Alexandria. Additionally, the authors would like to acknowledge the members of their departments for their helpful discussions and comments.

Conflicts of Interest: The authors declare no conflict of interest.

\section{References}

1. Abdelkhalek, A.; Hafez, E. Plant Viral Diseases in Egypt and Their Control. In Cottage Industry of Biocontrol Agents and Their Applications; Springer: Berlin/Heidelberg, Germany, 2020; pp. 403-421.

2. El-Helaly, H.S.; Ahmed, A.A.; Awad, M.A.; Soliman, A.M. Biological and molecular characterization of potato infecting alfalfa mosaic virus in Egypt. Int. J. Virol. 2012, 8, 106-113. [CrossRef]

3. Abdelkhalek, A.; Al-Askar, A.A.; Behiry, S.I. Bacillus licheniformis strain POT1 mediated polyphenol biosynthetic pathways genes activation and systemic resistance in potato plants against Alfalfa mosaic virus. Sci. Rep. 2020, 10, 16120. [CrossRef]

4. Mangeli, F.; Massumi, H.; Alipour, F.; Maddahian, M.; Heydarnejad, J.; Hosseinipour, A.; Amid-Motlagh, M.H.; Azizizadeh, M.; Varsani, A. Molecular and partial biological characterization of the coat protein sequences of Iranian alfalfa mosaic virus isolates. J. Plant Pathol. 2019, 101, 735-742. [CrossRef]

5. Trucco, V.; Castellanos Collazo, O.; Vaghi Medina, C.G.; Cabrera Mederos, D.; Lenardon, S.; Giolitti, F. Alfalfa mosaic virus (AMV): Genetic diversity and a new natural host. J. Plant Pathol. 2021, 1-8. [CrossRef]

6. Hosseini, S.A.; Ghaemi, M.; Khayyat, M. Responses of pepper to Alfalfa mosaic virus and manganese nutrition under greenhouse conditions: Preliminary results. J. Hortic. Postharvest Res. 2021, 4, 67-80.

7. Nie, X.; Dickison, V.; Singh, M.; De Koeyer, D.; Xu, H.; Bai, Y.; Hawkins, G. Potato tuber necrosis induced by alfalfa mosaic virus depends on potato cultivar rather than on virus strain. Plant Dis. 2020, 104, 340-347. [CrossRef] [PubMed]

8. Ormeño, J.; Sepúlveda, P.; Rojas, R.; Araya, J.E. Datura Genus Weeds as an Epidemiological Factor of Alfalfa mosaic virus (AMV), Cucumber mosaic virus (CMV), and Potato virus Y (PVY) on Solanaceus Crops. Agric. Técnica 2006, 66, 333. [CrossRef]

9. Abdelkhalek, A.; Salem, M.Z.M.; Ali, H.M.; Kordy, A.M.; Salem, A.Z.M.; Behiry, S.I. Antiviral, antifungal, and insecticidal activities of Eucalyptus bark extract: HPLC analysis of polyphenolic compounds. Microb. Pathog. 2020, 147, 104383. [CrossRef] [PubMed]

10. Abdelkhalek, A.; Salem, M.Z.M.; Hafez, E.; Behiry, S.I.; Qari, S.H. The Phytochemical, Antifungal, and First Report of the Antiviral Properties of Egyptian Haplophyllum tuberculatum Extract. Biology 2020, 9, 248. [CrossRef]

11. Sánchez-Estrada, A.; Tiznado-Hernández, M.E.; Ojeda-Contreras, A.J.; Valenzuela-Quintanar, A.I.; Troncoso-Rojas, R. Induction of Enzymes and Phenolic Compounds Related to the Natural Defence Response of Netted Melon Fruit by a Bio-elicitor. J. Phytopathol. 2009, 157, 24-32. [CrossRef]

12. McCann, H.C.; Nahal, H.; Thakur, S.; Guttman, D.S. Identification of innate immunity elicitors using molecular signatures of natural selection. Proc. Natl. Acad. Sci. USA 2012, 109, 4215-4220. [CrossRef] [PubMed]

13. Behiry, S.I.; Ashmawy, N.A.; Abdelkhalek, A.A.; Younes, H.A.; Khaled, A.E.; Hafez, E.E. Compatible- and incompatible-type interactions related to defense genes in potato elucidation by Pectobacterium carotovorum. J. Plant Dis. Prot. 2018, 125, 197-204. [CrossRef]

14. Hadwiger, L.A. Multiple effects of chitosan on plant systems: Solid science or hype. Plant Sci. 2013, 208, 42-49. [CrossRef] [PubMed] 
15. Hassan, O.; Chang, T. Chitosan for eco-friendly control of plant disease. Asian J. Plant Pathol. 2017, 11, 53-70. [CrossRef]

16. Chirkov, S.N. The antiviral activity of chitosan. Appl. Biochem. Microbiol. 2002, 38, 1-8. [CrossRef]

17. Davydova, V.N.; Nagorskaya, V.P.; Gorbach, V.I.; Kalitnik, A.A.; Reunov, A.V.; Solov'Eva, T.F.; Ermak, I.M. Chitosan antiviral activity: Dependence on structure and depolymerization method. Appl. Biochem. Microbiol. 2011, 47, 103-108. [CrossRef]

18. He, X.; Xing, R.; Liu, S.; Qin, Y.; Li, K.; Yu, H.; Li, P. The improved antiviral activities of amino-modified chitosan derivatives on Newcastle virus. Drug Chem. Toxicol. 2021, 44, 335-340. [CrossRef] [PubMed]

19. Chandra, S.; Chakraborty, N.; Dasgupta, A.; Sarkar, J.; Panda, K.; Acharya, K. Chitosan nanoparticles: A positive modulator of innate immune responses in plants. Sci. Rep. 2015, 5, 15195. [CrossRef]

20. Chun, S.-C.; Chandrasekaran, M. Chitosan and chitosan nanoparticles induced expression of pathogenesis-related proteins genes enhances biotic stress tolerance in tomato. Int. J. Biol. Macromol. 2019, 125, 948-954. [CrossRef]

21. Saharan, V.; Kumaraswamy, R.V.; Choudhary, R.C.; Kumari, S.; Pal, A.; Raliya, R.; Biswas, P. Cu-chitosan nanoparticle mediated sustainable approach to enhance seedling growth in maize by mobilizing reserved food. J. Agric. Food Chem. 2016, 64, 6148-6155. [CrossRef]

22. Kashyap, P.L.; Xiang, X.; Heiden, P. Chitosan nanoparticle based delivery systems for sustainable agriculture. Int. J. Biol. Macromol. 2015, 77, 36-51. [CrossRef] [PubMed]

23. Sathiyabama, M.; Manikandan, A. Foliar application of chitosan nanoparticle improves yield, mineral content and boost innate immunity in finger millet plants. Carbohydr. Polym. 2021, 258, 117691. [CrossRef]

24. Kheiri, A.; Jorf, S.A.M.; Malihipour, A.; Saremi, H.; Nikkhah, M. Application of chitosan and chitosan nanoparticles for the control of Fusarium head blight of wheat (Fusarium graminearum) in vitro and greenhouse. Int. J. Biol. Macromol. 2016, 93, 1261-1272. [CrossRef]

25. Heflish, A.A.; Hanfy, A.E.; Ansari, M.J.; Dessoky, E.S.; Attia, A.O.; Elshaer, M.M.; Gaber, M.K.; Kordy, A.; Doma, A.S.; Abdelkhalek, A. Green biosynthesized silver nanoparticles using Acalypha wilkesiana extract control root-knot nematode. J. King Saud Univ. 2021, 33, 101516. [CrossRef]

26. Abdelkhalek, A.; Al-Askar, A.A. Green Synthesized ZnO Nanoparticles Mediated by Mentha Spicata Extract Induce Plant Systemic Resistance against Tobacco mosaic Virus. Appl. Sci. 2020, 10, 5054. [CrossRef]

27. Fan, W.; Yan, W.; Xu, Z.; Ni, H. Formation mechanism of monodisperse, low molecular weight chitosan nanoparticles by ionic gelation technique. Colloids Surf. B Biointerfaces 2012, 90, 21-27. [CrossRef] [PubMed]

28. Abu-Saied, M.A.; Soliman, E.A.; Abualnaj, K.M.; El Desouky, E. Highly Conductive Polyelectrolyte Membranes Poly (vinyl alcohol)/Poly (2-acrylamido-2-methyl propane sulfonic acid)(PVA/PAMPS) for Fuel Cell Application. Polymers 2021, 13, 2638 [CrossRef] [PubMed]

29. Abu-Saied, M.A.; El-Desouky, E.A.; Soliman, E.A.; Abd El-Naim, G. Novel sulphonated poly (vinyl chloride)/poly (2-acrylamido2-methylpropane sulphonic acid) blends-based polyelectrolyte membranes for direct methanol fuel cells. Polym. Test. 2020, 89, 106604. [CrossRef]

30. Clark, M.F.; Adams, A.N. Characteristics of the microplate method of enzyme linked immunosorbent assay for the detection of plant viruses. J. Gen. Virol. 1977, 34, 475-483. [CrossRef]

31. Abdelkhalek, A.; Al-Askar, A.A.; Hafez, E. Differential induction and suppression of the potato innate immune system in response to Alfalfa mosaic virus infection. Physiol. Mol. Plant Pathol. 2020, 110, 101485. [CrossRef]

32. Abdelkhalek, A.; Qari, S.H.S.H.; Hafez, E. Iris yellow spot virus-induced chloroplast malformation results in male sterility. J. Biosci. 2019, 44, 142. [CrossRef]

33. Abdelkhalek, A.; Sanan-Mishra, N. A comparative analysis of the suppressor activity of Tobacco mosaic virus proteins in the tomato plant. Jordan J. Biol. Sci. 2018, 11, 469-473.

34. Abdelkhalek, A. Expression of tomato pathogenesis related genes in response to Tobacco mosaic virus. JAPS J. Anim. Plant Sci. 2019, 29, 1596-1602.

35. Jindal, K.K.; Singh, R.N. Phenolic content in male and female Carica papaya: A possible physiological marker for sex identification of vegetative seedlings. Physiol. Plant. 1975, 33, 104-107. [CrossRef]

36. Dubois, M.; Gilles, K.A.; Hamilton, J.K.; Rebers, P.T.; Smith, F. Colorimetric method for determination of sugars and related substances. Anal. Chem. 1956, 28, 350-356. [CrossRef]

37. Chomczynski, P.; Sacchi, N. The single-step method of RNA isolation by acid guanidinium thiocyanate-phenol-chloroform extraction: Twenty-something years on. Nat. Protoc. 2006, 1, 581-585. [CrossRef] [PubMed]

38. Abdelkhalek, A.; Sanan-Mishra, N. Differential expression profiles of tomato miRNAs induced by Tobacco mosaic virus. J. Agric. Sci. Technol. 2019, 21, 475-485.

39. Abdelkhalek, A.; Ismail, I.A.I.A.; Dessoky, E.S.E.S.; El-Hallous, E.I.E.I.; Hafez, E. A tomato kinesin-like protein is associated with Tobacco mosaic virus infection. Biotechnol. Biotechnol. Equip. 2019, 33, 1424-1433. [CrossRef]

40. Hafez, E.E.; Abdelkhalek, A.A.; Abd El-Wahab, A.S.E.-D.; Galal, F.H. Altered gene expression: Induction/suppression in leek elicited by Iris Yellow Spot Virus infection (IYSV) Egyptian isolate. Biotechnol. Biotechnol. Equip. 2013, 27, 4061-4068. [CrossRef]

41. Livak, K.J.; Schmittgen, T.D. Analysis of relative gene expression data using real-time quantitative PCR and the $2^{-\Delta \Delta C T}$ method. Methods 2001, 25, 402-408. [CrossRef]

42. Kätzel, U.; Vorbau, M.; Stintz, M.; Gottschalk-Gaudig, T.; Barthel, H. Dynamic light scattering for the characterization of polydisperse fractal systems: II. Relation between structure and DLS results. Part. Part. Syst. Charact. 2008, 25, 19-30. [CrossRef] 
43. Mohy Eldin, M.S.; Tamer, T.M.; Abu Saied, M.A.; Soliman, E.A.; Madi, N.K.; Ragab, I.; Fadel, I. Click grafting of chitosan onto PVC surfaces for biomedical applications. Adv. Polym. Technol. 2018, 37, 38-49. [CrossRef]

44. Abu-Saied, M.A.; Soliman, E.A.; Al Desouki, E.A. Development of Proton Exchange Membranes Based on Chitosan Blended with Poly (2-Acrylamido-2-Methylpropane Sulfonic Acid) for Fuel Cells applications. Mater. Today Commun. 2020, $25,101536$. [CrossRef]

45. Chavan, C.; Bala, P.; Pal, K.; Kale, S.N. Cross-linked chitosan-dextran sulphate vehicle system for controlled release of ciprofloxaxin drug: An ophthalmic application. OpenNano 2017, 2, 28-36. [CrossRef]

46. Sarmento, B.; Martins, S.; Ribeiro, A.; Veiga, F.; Neufeld, R.; Ferreira, D. Development and comparison of different nanoparticulate polyelectrolyte complexes as insulin carriers. Int. J. Pept. Res. Ther. 2006, 12, 131-138. [CrossRef]

47. El-Abhar, M.; El-Abhar, M.A.; Elkady, M.A.; Ghanem, K.M.; Bosila, H.A. Identification, characterization and ultrastructure aspects of Alfalfa mosaic virus infecting potato (Solanum tuberosum L.) in Egypt. J. Virol. Sci. 2018, 3, 68-77.

48. Zitikaite, I.; Samuitienè, M. Identification and some properties of Alfalfa mosaic alfamovirus isolated from naturally infected tomato crop. Biologija 2008, 2, 83-88. [CrossRef]

49. Aleem, E.E.A.; Taha, R.M.; Fattouh, F.A. Biodiversity and full genome sequence of potato viruses Alfalfa mosaic virus and potato leaf roll virus in Egypt. Zeitschrift für Naturforsch. C 2018, 73, 423-438. [CrossRef]

50. Parrella, G.; Lanave, C.; Marchoux, G.; Sialer, M.M.F.; Di Franco, A.; Gallitelli, D. Evidence for two distinct subgroups of Alfalfa mosaic virus (AMV) from France and Italy and their relationships with other AMV strains. Arch. Virol. 2000, 145, 2659-2667. [CrossRef]

51. Rendina, N.; Nuzzaci, M.; Scopa, A.; Cuypers, A.; Sofo, A. Chitosan-elicited defense responses in Cucumber mosaic virus (CMV)-infected tomato plants. J. Plant Physiol. 2019, 234, 9-17. [CrossRef]

52. Van, S.N.; Minh, H.D.; Anh, D.N. Study on chitosan nanoparticles on biophysical characteristics and growth of Robusta coffee in green house. Biocatal. Agric. Biotechnol. 2013, 2, 289-294.

53. Hong, J.; Wang, C.; Wagner, D.C.; Gardea-Torresdey, J.L.; He, F.; Rico, C.M. Foliar application of nanoparticles: Mechanisms of absorption, transfer, and multiple impacts. Environ. Sci. Nano 2021, 8, 1196-1210. [CrossRef]

54. Yang, X.X.; Li, C.M.; Huang, C.Z. Curcumin modified silver nanoparticles for highly efficient inhibition of respiratory syncytial virus infection. Nanoscale 2016, 8, 3040-3048. [CrossRef] [PubMed]

55. Cai, L.; Cai, L.; Jia, H.; Liu, C.; Wang, D.; Sun, X. Foliar exposure of $\mathrm{Fe}_{3} \mathrm{O}_{4}$ nanoparticles on Nicotiana benthamiana: Evidence for nanoparticles uptake, plant growth promoter and defense response elicitor against plant virus. J. Hazard. Mater. 2020, $393,122415$. [CrossRef]

56. Xing, K.; Zhu, X.; Peng, X.; Qin, S. Chitosan antimicrobial and eliciting properties for pest control in agriculture: A review. Agron. Sustain. Dev. 2015, 35, 569-588. [CrossRef]

57. Noha, K.; Bondok, A.M.; El-Dougdoug, K.A. Evaluation of silver nanoparticles as antiviral agent against ToMV and PVY in tomato plants. Sciences 2018, 8, 100-111.

58. Nagorskaya, V.; Reunov, A.; Lapshina, L.; Davydova, V.; Yermak, I. Effect of chitosan on tobacco mosaic virus (TMV) accumulation, hydrolase activity, and morphological abnormalities of the viral particles in leaves of N. tabacum L. cv. Samsun. Virol. Sin. 2014, 29, 250-256. [CrossRef] [PubMed]

59. Hu, Y.; Cai, J.; Du, Y.; Lin, J.; Wang, C.; Xiong, K. Preparation and anti-TMV activity of guanidinylated chitosan hydrochloride. J. Appl. Polym. Sci. 2009, 112, 3522-3528. [CrossRef]

60. Chirkov, S.N.; Il'ina, A.V.; Surgucheva, N.A.; Letunova, E.V.; Varitsev, Y.A.; Tatarinova, N.Y.; Varlamov, V.P. Effect of chitosan on systemic viral infection and some defense responses in potato plants. Russ. J. Plant Physiol. 2001, 48, 774-779. [CrossRef]

61. Sinniah, U.R.; Ellis, R.H.; John, P. Irrigation and seed quality development in rapid-cycling brassica: Soluble carbohydrates and heat-stable proteins. Ann. Bot. 1998, 82, 647-655. [CrossRef]

62. Ahmed, S.; Nawata, E.; Sakuratani, T. Changes of endogenous ABA and ACC, and their correlations to photosynthesis and water relations in mungbean (Vigna radiata (L.) Wilczak cv. KPS1) during waterlogging. Environ. Exp. Bot. 2006, 57, 278-284. [CrossRef]

63. Nazar, R.; Iqbal, N.; Masood, A.; Khan, M.I.R.; Syeed, S.; Khan, N.A. Cadmium toxicity in plants and role of mineral nutrients in its alleviation. Am. J. Plant Sci. 2012, 10, 1476-1489. [CrossRef]

64. Hoekstra, F.A.; Golovina, E.A.; Buitink, J. Mechanisms of plant desiccation tolerance. Trends Plant Sci. 2001, 6, 431-438. [CrossRef]

65. Gaddam, S.A.; Kotakadi, V.S.; Reddy, M.N.; Saigopal, D.V.R. Antigenic relationships of Citrus yellow mosaic virus by immunological methods. Asian J. Plant Sci. Res. 2012, 2, 566-569.

66. Arias, M.C.; Lenardon, S.; Taleisnik, E. Carbon metabolism alterations in sunflower plants infected with the Sunflower chlorotic mottle virus. J. Phytopathol. 2003, 151, 267-273. [CrossRef]

67. Goodman, P.J.; Watson, M.A.; Hill, A.R.C. Sugar and fructosan accumulation in virus-infected plants: Rapid testing by circularpaper chromatography. Ann. Appl. Biol. 1965, 56, 65-72. [CrossRef]

68. Khalid, M.; Siddiqui, H.H.; Freed, S. In-vitro assessment of antioxidant activity of Dalbergia latifolia barks extract against free radicals. Am. J. Sci. Res. 2011, 6, 172-177.

69. Behiry, S.I.; Okla, M.K.; Alamri, S.A.; El-Hefny, M.; Salem, M.Z.M.; Alaraidh, I.A.; Ali, H.M.; Al-Ghtani, S.M.; Monroy, J.C.; Salem, A.Z.M. Antifungal and antibacterial activities of Musa paradisiaca L. peel extract: HPLC analysis of phenolic and flavonoid contents. Processes 2019, 7, 215. [CrossRef] 
70. Al-Huqail, A.A.; Behiry, S.I.; Salem, M.Z.M.; Ali, H.M.; Siddiqui, M.H.; Salem, A.Z.M. Antifungal, antibacterial, and antioxidant activities of Acacia saligna (Labill.) HL Wendl. flower extract: HPLC analysis of phenolic and flavonoid compounds. Molecules 2019, 24, 700. [CrossRef] [PubMed]

71. Ashmawy, N.A.; Behiry, S.I.; Al-Huqail, A.A.; Ali, H.M.; Salem, M.Z.M. Bioactivity of Selected Phenolic Acids and Hexane Extracts from Bougainvilla spectabilis and Citharexylum spinosum on the Growth of Pectobacterium carotovorum and Dickeya solani Bacteria: An Opportunity to Save the Environment. Processes 2020, 8, 482. [CrossRef]

72. Aly, A.A.; Mansour, M.T.M.; Mohamed, H.I. Association of increase in some biochemical components with flax resistance to powdery mildew. Gesunde Pflanz. 2017, 69, 47-52. [CrossRef]

73. Radwan, D.E.M.; Fayez, K.A.; Mahmoud, S.Y.; Lu, G. Modifications of antioxidant activity and protein composition of bean leaf due to Bean yellow mosaic virus infection and salicylic acid treatments. Acta Physiol. Plant. 2010, 32, 891-904. [CrossRef]

74. Mejía-Teniente, L.; Durán-Flores, F.D.D.; Chapa-Oliver, A.M.; Torres-Pacheco, I.; Cruz-Hernández, A.; González-Chavira, M.M.; Ocampo-Velázquez, R.V.; Guevara-González, R.G. Oxidative and molecular responses in Capsicum annuum L. after hydrogen peroxide, salicylic acid and chitosan foliar applications. Int. J. Mol. Sci. 2013, 14, 10178-10196. [CrossRef] [PubMed]

75. Isamah, G.K.; Asagba, S.O.; Thomas, A.E. Lipid peroxidation, o-diphenolase, superoxide dismutase and catalase profile along the three physiological regions of Dioscorea rotundata Poir cv Omi. Food Chem. 2000, 69, 1-4. [CrossRef]

76. Han, Y.; Luo, Y.; Qin, S.; Xi, L.; Wan, B.; Du, L. Induction of systemic resistance against tobacco mosaic virus by Ningnanmycin in tobacco. Pestic. Biochem. Physiol. 2014, 111, 14-18. [CrossRef] [PubMed]

77. Venkatesan, S.; Radjacommare, R.; Nakkeeran, S.; Chandrasekaran, A. Effect of biocontrol agent, plant extracts and safe chemicals in suppression of mungbean yellow mosaic virus (MYMV) in black gram (Vigna mungo). Arch. Phytopathol. Plant Prot. 2010, 43, 59-72. [CrossRef]

78. Gonçalves, L.S.A.; Rodrigues, R.; Diz, M.S.S.; Robaina, R.R.; Júnior, A.; Carvalho, A.; Gomes, V. Peroxidase is involved in Pepper yellow mosaic virus resistance in Capsicum baccatum var. pendulum. Genet. Mol. Res. 2013, 12, 1411-1420. [CrossRef] [PubMed]

79. Batra, G.K.; Kuhn, C.W. Polyphenoloxidase and peroxidase activities associated with acquired resistance and its inhibition by 2-thiouracil in virus-infected soybean. Physiol. Plant Pathol. 1975, 5, 239-248. [CrossRef]

80. Buonaurio, R.; Montalbini, P. Tobacco mosaic virus induced systemic changes in the peroxidase activity and isoperoxidase pattern in tobacco leaves and the relation to acquired resistance to powdery mildew infection. Phytopathol. Mediterr. 1995, 34, $184-191$.

81. Sathiyabama, M.; Manikandan, A. Chitosan nanoparticle induced defense responses in fingermillet plants against blast disease caused by Pyricularia grisea (Cke.) Sacc. Carbohydr. Polym. 2016, 154, 241-246. [CrossRef]

82. Liu, R.; Wang, Z.-Y.; Li, T.-T.; Wang, F.; An, J. The role of chitosan in polyphenols accumulation and induction of defense enzymes in Pinus koraiensis seedlings. Chin. J. Plant Ecol. 2014, 38, 749.

83. Siddaiah, C.N.; Prasanth, K.V.H.; Satyanarayana, N.R.; Mudili, V.; Gupta, V.K.; Kalagatur, N.K.; Satyavati, T.; Dai, X.-F.; Chen, J.-Y.; Mocan, A. Chitosan nanoparticles having higher degree of acetylation induce resistance against pearl millet downy mildew through nitric oxide generation. Sci. Rep. 2018, 8, 2485. [CrossRef]

84. Yang, F.; Hu, J.; Li, J.; Wu, X.; Qian, Y. Chitosan enhances leaf membrane stability and antioxidant enzyme activities in apple seedlings under drought stress. Plant Growth Regul. 2009, 58, 131-136. [CrossRef]

85. Choudhary, R.C.; Kumaraswamy, R.V.; Kumari, S.; Sharma, S.S.; Pal, A.; Raliya, R.; Biswas, P.; Saharan, V. Cu-chitosan nanoparticle boost defense responses and plant growth in maize (Zea mays L.). Sci. Rep. 2017, 7, 9754. [CrossRef] [PubMed]

86. Vlot, A.C.; Dempsey, D.A.; Klessig, D.F. Salicylic acid, a multifaceted hormone to combat disease. Annu. Rev. Phytopathol. 2009, 47, 177-206. [CrossRef] [PubMed]

87. D’Maris Amick Dempsey, A.C.; Vlot, M.C.W.; Daniel, F.K.; Dempsey, D.A.; Vlot, A.C.; Wildermuth, M.C.; Klessig, D.F.; D’Maris Amick Dempsey, A.C.; Vlot, M.C.W.; Daniel, F.K.; et al. Salicylic acid biosynthesis and metabolism. Arab. Book/Am. Soc. Plant Biol. 2011, 9, e0156. [CrossRef]

88. Lincoln, J.E.; Sanchez, J.P.; Zumstein, K.; Gilchrist, D.G. Plant and animal PR1 family members inhibit programmed cell death and suppress bacterial pathogens in plant tissues. Mol. Plant Pathol. 2018, 19, 2111-2123. [CrossRef]

89. Heflish, A.A.; Abdelkhalek, A.; Al-Askar, A.A.; Behiry, S.I. Protective and Curative Effects of Trichoderma asperelloides Ta41 on Tomato Root Rot Caused by Rhizoctonia solani Rs33. Agronomy 2021, 11, 1162. [CrossRef]

90. Ali, S.; Ganai, B.A.; Kamili, A.N.; Bhat, A.A.; Mir, Z.A.; Bhat, J.A.; Tyagi, A.; Islam, S.T.; Mushtaq, M.; Yadav, P. Pathogenesisrelated proteins and peptides as promising tools for engineering plants with multiple stress tolerance. Microbiol. Res. 2018, 212, 29-37. [CrossRef]

91. Cutt, J.R.; Harpster, M.H.; Dixon, D.C.; Carr, J.P.; Dunsmuir, P.; Klessig, D.F. Disease response to tobacco mosaic virus in transgenic tobacco plants that constitutively express the pathogenesis-related PR1b gene. Virology 1989, 173, 89-97. [CrossRef]

92. Su, H.; Song, S.; Yan, X.; Fang, L.; Zeng, B.; Zhu, Y. Endogenous salicylic acid shows different correlation with baicalin and baicalein in the medicinal plant Scutellaria baicalensis Georgi subjected to stress and exogenous salicylic acid. PLoS ONE 2018, 13, $\mathrm{e} 0192114$.

93. Abdelkhalek, A.; Dessoky, E.S.; Hafez, E. Polyphenolic genes expression pattern and their role in viral resistance in tomato plant infected with Tobacco mosaic virus. Biosci. Res. 2018, 15, 3349-3356.

94. Hao, Q.; Wang, W.; Han, X.; Wu, J.; Lyu, B.; Chen, F.; Caplan, A.; Li, C.; Wu, J.; Wang, W. Isochorismate-based salicylic acid biosynthesis confers basal resistance to Fusarium graminearum in barley. Mol. Plant Pathol. 2018, 19, 1995-2010. [CrossRef] [PubMed] 
95. Chen, Z.; Zheng, Z.; Huang, J.; Lai, Z.; Fan, B. Biosynthesis of salicylic acid in plants. Plant Signal. Behav. 2009, 4, 493-496. [CrossRef]

96. Nehela, Y.; Hijaz, F.; Elzaawely, A.A.; El-Zahaby, H.M.; Killiny, N. Citrus phytohormonal response to Candidatus Liberibacter asiaticus and its vector Diaphorina citri. Physiol. Mol. Plant Pathol. 2018, 102, 24-35. [CrossRef]

97. Iriti, M.; Faoro, F. Chitosan as a MAMP, searching for a PRR. Plant Signal. Behav. 2009, 4, 66-68. [CrossRef]

98. Xu, X.L.; Olson, J.M.; Zhao, L.P. A regression-based method to identify differentially expressed genes in microarray time course studies and its application in an inducible Huntington's disease transgenic model. Hum. Mol. Genet. 2002, 11, 1977-1985. [CrossRef]

99. Liu, S.; Lu, M.; Li, H.; Zuo, Y. Prediction of gene expression patterns with generalized linear regression model. Front. Genet. 2019, 10, 120. [CrossRef] [PubMed]

100. Mallik, S.; Seth, S.; Bhadra, T.; Zhao, Z. A linear regression and deep learning approach for detecting reliable genetic alterations in cancer using dna methylation and gene expression data. Genes 2020, 11, 931. [CrossRef] [PubMed]

101. Duren, Z.; Chen, X.; Jiang, R.; Wang, Y.; Wong, W.H. Modeling gene regulation from paired expression and chromatin accessibility data. Proc. Natl. Acad. Sci. USA 2017, 114, E4914-E4923. [CrossRef]

102. Liu, H.; Tarima, S.; Borders, A.S.; Getchell, T.V.; Getchell, M.L.; Stromberg, A.J. Quadratic regression analysis for gene discovery and pattern recognition for non-cyclic short time-course microarray experiments. BMC Bioinform. 2005, 6, 106. [CrossRef] 